Prepared in cooperation with the U.S. Environmental Protection Agency

\title{
Particle Tracking for Selected Groundwater Wells in the Lower Yakima River Basin, Washington
}

\section{$4 x^{2}+2 y$}

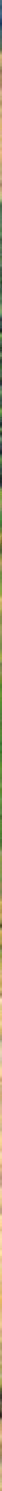


Cover: Photograph of Sunnyside Canal looking north, northwest approximately 5 miles southeast of the Sunnyside Diversion Dam on the Yakima River, Yakima, Washington, 2002. Photograph by David Walsh, Bureau of Reclamation. 


\section{Particle Tracking for Selected Groundwater Wells in the Lower Yakima River Basin, Washington}

By Matthew P. Bachmann

Prepared in cooperation with the U.S. Environmental Protection Agency

Scientific Investigations Report 2015-5149 


\title{
U.S. Department of the Interior SALLY JEWELL, Secretary
}

\section{U.S. Geological Survey \\ Suzette M. Kimball, Acting Director}

\author{
U.S. Geological Survey, Reston, Virginia: 2015
}

For more information on the USGS - the Federal source for science about the Earth, its natural and living resources, natural hazards, and the environment—visit http://www.usgs.gov or call 1-888-ASK-USGS.

For an overview of USGS information products, including maps, imagery, and publications, visit http://www.usgs.gov/pubprod/.

Any use of trade, firm, or product names is for descriptive purposes only and does not imply endorsement by the U.S. Government.

Although this information product, for the most part, is in the public domain, it also may contain copyrighted materials as noted in the text. Permission to reproduce copyrighted items must be secured from the copyright owner.

Suggested citation:

Bachmann, M.P., 2015, Particle tracking for selected groundwater wells in the lower Yakima River Basin, Washington: U.S. Geological Survey Scientific Investigations Report 2015-5149, 33 p., http://dx.doi.org/10.3133/sir20155149.

ISSN 2328-0328 (online) 


\section{Contents}

Abstract
Introduction.
Purpose and Scope
Simulation of Particle Tracking
Stress Periods
Discretization
Pedel Inputs
Surticle Tracking




\section{Figures}

1. Map showing the Yakima River Basin, Washington ...

2. Map showing location of structural basins and geologic structures, Yakima River Basin, Washington.

3. Map showing simplified surficial geology in the Yakima River Basin, Washington...........5

4. Map showing location and extent of the groundwater-flow model grid used to simulate the Yakima River Basin aquifer system, Washington

5. Map showing location of model cross section through the Toppenish/Benton subbasin and hydrogeologic section showing relation of model hydrogeologic units to model computational layers, Yakima River Basin aquifer system, Washington.

6. Map showing location of the groundwater-flow model boundary conditions for drains, general and specified heads, and streamflow routing cells, Yakima River Basin aquifer system, Washington.

7. Map showing spatial distribution of mean annual recharge simulated for 1960-2001, Yakima River Basin aquifer system, Washington.

8. Map showing location of model structures and flow barrier conductivity, Yakima River Basin aquifer system, Washington.

9. Graph showing weighted measured values as a function of weighted simulated values, Yakima River Basin aquifer system, Washington..

10. Map showing locations of 121 groundwater samples with nitrate concentrations exceeding 10 milligrams per liter, lower Yakima River Valley, Washington, 2008-2011.

11. Map showing simulated particle histories for particles that ended the 42-year simulation period at the location of model cells containing selected groundwater wells in the lower Yakima River Basin, Washington ....

12. Maps showing modeled structural barriers to groundwater flow in some locations cause particle flow paths to change direction sharplyand seasonally varying recharge patterns and associated changes in hydraulic head gradients cause some particle paths to temporarily reverse direction, Yakima River Basin, Washington

13. Maps showing recharge capture areas defined by particle ending locations outlining the area contributing recharge, and all area circumscribed by particle pathways outlining the areal extent of the zone of contribution for a group of six groundwater sampling locations near Zillah, Washington

14. Maps showing zones of contribution for a dense area of wells near Granger, Washington, divided into two groups to make individual particle pathlines more visible in a location where areas contributing recharge to specific wells overlap heavily.....

15. Map showing simulated zones of contribution for the model cells containing the 121 contaminated wells in the lower Yakima River Basin, Washington.

\section{Tables}

1. Descriptive statistics for the thickness of groundwater model layers used to simulate the Yakima River Basin aquifer system, Washington.

2. Calibrated model parameter values for the Yakima River Basin aquifer system, Washington 


\section{Conversion Factors}

Inch/Pound to International System of Units

\begin{tabular}{lcl}
\hline \multicolumn{1}{c}{ Multiply } & \multicolumn{1}{c}{ By } & \multicolumn{1}{c}{ To obtain } \\
\hline foot $(\mathrm{ft})$ & Length & \\
mile $(\mathrm{mi})$ & 0.3048 & meter $(\mathrm{m})$ \\
\hline & 1.609 & kilometer $(\mathrm{km})$ \\
\hline acre & Area & \\
acre & 4,047 & square meter $\left(\mathrm{m}^{2}\right)$ \\
square foot $\left(\mathrm{ft}^{2}\right)$ & 0.004047 & square kilometer $\left(\mathrm{km}^{2}\right)$ \\
square mile $\left(\mathrm{mi}^{2}\right)$ & 0.09290 & square meter $\left(\mathrm{m}^{2}\right)$ \\
& 2.590 & square kilometer $\left(\mathrm{km}^{2}\right)$ \\
\hline acre-foot $($ acre-ft) & Volume & \\
acre-foot $($ acre-ft) & 1,233 & cubic meter $\left(\mathrm{m}^{3}\right)$ \\
& 0.001233 & cubic hectometer $\left(\mathrm{hm}^{3}\right)$ \\
\hline acre-foot per year $(\mathrm{acre}-\mathrm{ft} / \mathrm{yr})$ & Flow rate & \\
acre-foot per year $(\mathrm{acre}-\mathrm{ft} / \mathrm{yr})$ & 1,233 & cubic meter per year $\left(\mathrm{m}^{3} / \mathrm{yr}\right)$ \\
foot per day $(\mathrm{ft} / \mathrm{d})$ & 0.001233 & cubic hectometer per year $(\mathrm{hm} 3 / \mathrm{yr})$ \\
square foot per day $\left(\mathrm{ft}^{2} / \mathrm{d}\right)$ & 0.3048 & meter per day $(\mathrm{m} / \mathrm{d})$ \\
cubic foot per second $\left(\mathrm{ft}^{3} / \mathrm{s}\right)$ & 0.09290 & square meter per day $\left(\mathrm{m}^{2} \mathrm{~d}\right)$ \\
\hline
\end{tabular}

International System of Units to Inch/Pound

\begin{tabular}{lcc}
\hline & Bultiply & To obtain \\
\hline & \multicolumn{1}{c}{ Volume } & \\
\hline liter (L) & 1.057 & quart (qt) \\
\hline \multicolumn{2}{c}{ Mass } \\
\hline milligram (mg) & 0.00003527396 & ounce, avoirdupois (oz)
\end{tabular}

Concentrations of chemical constituents in water are given in milligrams per liter (mg/L).

\section{Datums}

Vertical coordinate information is referenced to the North American Vertical Datum of 1988 (NAVD 88).

Horizontal coordinate information is referenced to the North American Datum of 1927 (NAD 27) and the North American Datum of 1983 (NAD 83).

Elevation, as used in this report, refers to distance above the vertical datum. 



\title{
Particle Tracking for Selected Groundwater Wells in the Lower Yakima River Basin, Washington
}

\author{
By Matthew P. Bachmann
}

\section{Abstract}

The Yakima River Basin in south-central Washington has a long history of irrigated agriculture and a more recent history of large-scale livestock operations, both of which may contribute nutrients to the groundwater system. Nitrate concentrations in water samples from shallow groundwater wells in the lower Yakima River Basin exceeded the U.S. Environmental Protection Agency drinking-water standard, generating concerns that current applications of fertilizer and animal waste may be exceeding the rate at which plants can uptake nutrients, and thus contributing to groundwater contamination.

The U.S. Geological Survey (USGS) recently completed a regional scale transient three-dimensional groundwater-flow model of the Yakima River Basin using MODFLOW-2000. The model was used with the USGS particle-tracking code MODPATH to generate advective flowpaths and associated travel times. Analyses used particle backtracking in time from September 2001 through 504 monthly stress periods to October 1959 or until pathlines terminated at a model boundary. The particle starting locations were assigned to 1,000 foot square computational model cells containing one or more of the 121 sampling locations with measured nitrate concentrations greater than the U.S. Environmental Protection Agency drinking-water standard for nitrate (10 milligrams per liter $[\mathrm{mg} / \mathrm{L}])$. Of the 2,403 particles, the simulated pathlines for 2,080 reached the water table within the 42-year simulation period, thus identifying the predicted recharge areas for those particles. The median horizontal straight-line distance was 13,194 feet between starting and ending locations for these particles and the median time-of-travel for particles that intersected the water table was 984 days. Well to water-table travel times for 75.4 percent of the particles were less than the average travel time of 3,749 days. Predicted recharge locations for all particles, including those that did not reach the water table in 42 years, were between 50 feet and 34 miles horizontal distance from their starting locations, with a median distance of less than 3 miles away.

Generalized groundwater-flow directions in unconsolidated basin-fill deposits were towards the Yakima River, which acts as a local sink for shallow groundwater, and roughly parallel to topographic gradients. Particles backtracked from more shallow aquifer locations traveled shorter distances before reaching the water table than particles from deeper locations. Flowpaths for particles starting at wells completed in the basalt units underlying the basin-fill deposits sometimes were different than for wells with similar lateral locations but more shallow depths. In cases where backtracking particles reached geologic structures simulated as flow barriers, abrupt changes in direction in some particle pathlines suggest significant changes in simulated hydraulic gradients that may not accurately reflect actual conditions. Most groundwater wells sampled had associated zones of contribution within the Toppenish/Benton subbasin between the well and the nearest subbasin margin, but interpretation of these results for any specific well is likely to be complicated by the assumptions and simplifications inherent in the model construction process. Delineated zones of contribution for individual wells are sensitive to the depths assigned to the screened interval of the well, resulting in simulated areal extents of the zones of contribution to a discharging well that are elongated in the direction of groundwater flow.

\section{Introduction}

The Yakima River Basin in south-central Washington covers 6,200 $\mathrm{mi}^{2}$ and includes parts of Yakima, Kittitas, and Benton Counties, and part of the Yakama Indian Reservation (fig. 1). Several water-quality investigations in recent decades have measured nitrate concentrations exceeding the U.S. Environmental Protection Agency (EPA) drinking water standard of $10 \mathrm{mg} / \mathrm{L}$ in shallow drinking-water wells, primarily in the lower valley Toppenish/Benton subbasin (U.S. Environmental Protection Agency, 2012, Washington State Department of Ecology 2010). The contaminated drinking-water wells tend to be shallow, and in many cases are primarily used by Tribal members of the Yakama Nation and Spanish-speaking families participating in the local agricultural economy (Washington State Department of Ecology, 2010). 


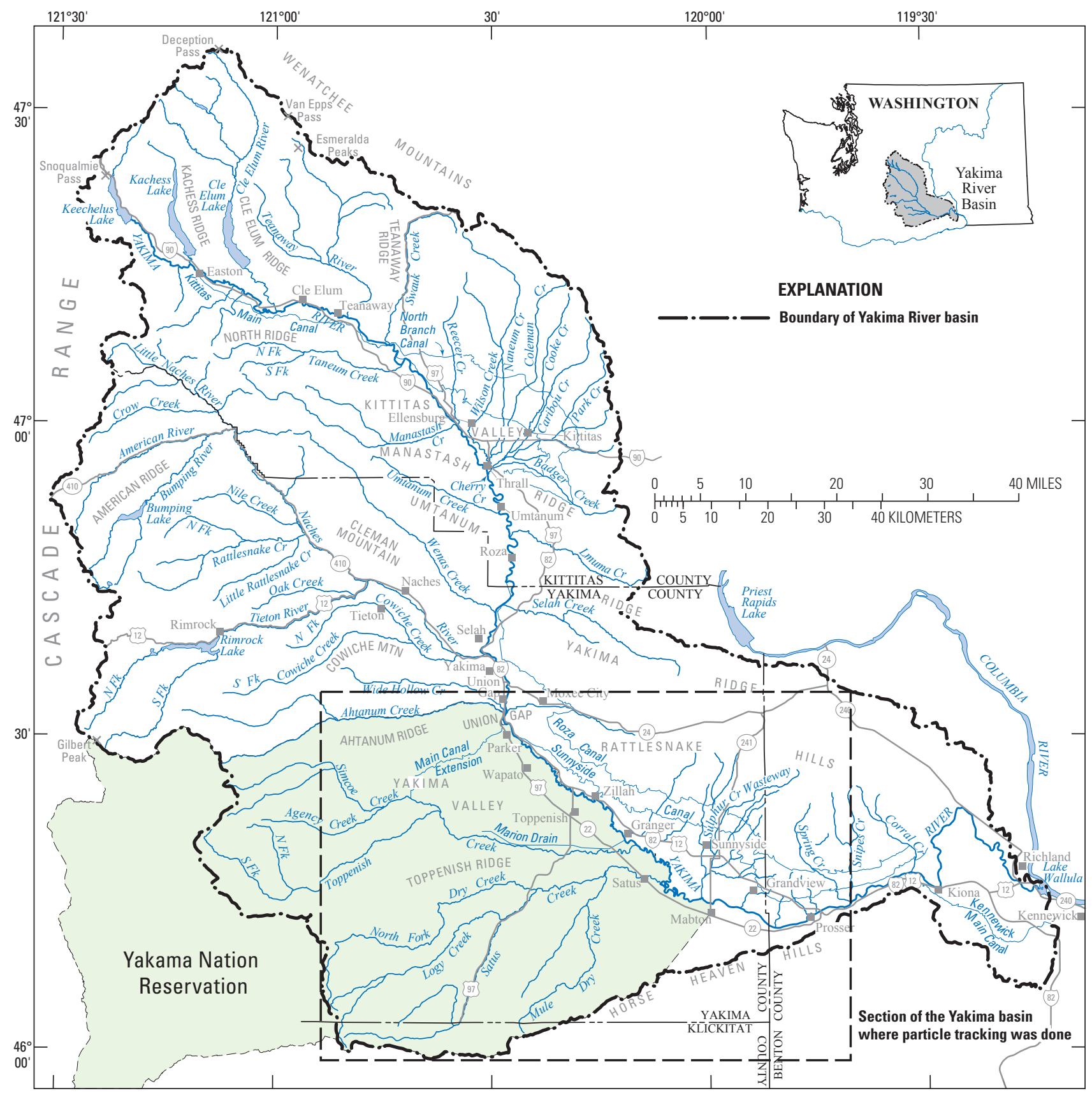

Base from U.S. Geological Survey and/or

Washington Division of Geology and Earth Resources

digital data, 1983, 1:100,000

Universal Transverse Mercator projection, Zone 10

Horizontal Datum: North American Datum of 1927 (NAD 27)

Figure 1. Yakima River Basin, Washington. 
Substantial amounts of nitrogen have been applied to the land in the Yakima River Basin for decades, primarily as fertilizer for row crops, but in recent years also as animal waste generated by more than 60 animal feeding operations (Washington State Department of Ecology, 2010). Although water-quality sampling for nutrients in the basin has a long history (Van Winkle, 1914), there has been little work attempting to link specific contaminated wells to any identified land uses or locations of contaminant loading. The completion of a transient three-dimensional groundwaterflow model of the Yakima River Basin (Ely and others, 2011), which documents groundwater-flow directions and hydraulic conductivities for each mapped hydrogeologic unit in the basin, has made possible the identification of simulated travel times and contributing areas for specific groundwater wells. For this purpose, the particle-tracking code MODPATH 5.0 (Pollock, 1994) was used for particle backtracking from the estimated point of extraction for selected groundwater sampling locations to simulated source areas. For pathlines that terminated at the water table, the particle tracking analysis connects water from a groundwater well to an area of land surface that contributed recharge to that well, and is not specific to any groundwater contaminant or land use practice.

\section{Purpose and Scope}

The purpose of this report is to describe the results of using an existing transient groundwater-flow model of the Yakima River Basin in conjunction with a particle-tracking program to document localized groundwater-flow directions and velocities, to estimate time-of-travel for groundwater to flow from the water table to selected wells, and to identify locations where nitrates applied to land surface may contribute to nitrate concentrations measured in groundwater samples that exceed the EPA drinking-water standard of $10 \mathrm{mg} / \mathrm{L}$ (U.S. Environmental Protection Agency, 2012).

The MODFLOW-2000 groundwater-flow model of the Yakima Basin developed by Ely and others (2011) was used to generate flow directions for every computational model cell. That model was constructed for the purpose of evaluating regional scale water-management scenarios and exchanges between groundwater and surface-water features such as rivers, streams, and tile drains. The size of the model cells and duration of the model time steps were formulated to address regional scale system responses and features and are not ideally suited for the analysis of individual wells. Thus, the results of this particle-tracking analysis only approximates actual groundwater-flow paths.

Although the groundwater sampling locations (wells) used to determine particle-tracking starting locations in this analysis were selected because of their measured nitrate concentrations, no part of the nitrogen cycle is explicitly simulated by either MODFLOW-2000 or MODPATH. Particle-tracking starting, ending, and intermediate locations are provided based on groundwater flowpath travel time but concentrations of nitrate or any other solute are not simulated or reported. The particle-tracking results can be used to identify the direction and rate of groundwater flow at various depths in the aquifer system, the land-surface areas that contribute recharge to a specific simulated model cell containing one or more groundwater wells, and the time-oftravel required for groundwater to move along the simulated flowpaths. This analysis considers only nonreactive advective transport and as such macro-scale hydrodynamic dispersion, diffusion and other processes that may attenuate or retard contaminant concentrations, such as adsorption or chemical transformations, are not considered. Thus, the results are most applicable to chemically conservative groundwater contaminants that are fully miscible in groundwater. EPA measured nearly 200 different analytes in these samples, including major ions and trace metals, perchlorate, fecal coliform, pesticides, and wastewater pharmaceuticals, and identified elevated concentrations in multiple drinking-water sources (U.S. Environmental Protection Agency, 2012).

\section{Description of Study Area}

The modeled area of the Yakima River Basin in Washington extends from the crest of the Cascade Mountains east to the Columbia River. Unregulated streamflow averages 4.1 million acre-ft/yr, and is subject to five managed storage reservoirs and diversions to irrigated agriculture of about 2.8 million acre-ft/yr (Ely and others, 2011). The basin is separated into several broad valleys by east-west trending anticlinal ridges that separate valley floors that slope gently toward the Yakima River. These valleys contain most of the population and economic activity in the basin. The Toppenish/Benton subbasin, the largest and most southerly of the five structural subbasins, encompasses almost $1,500 \mathrm{mi}^{2}$ between Ahtanum Ridge and Rattlesnake Hills on the north and Toppenish Ridge and the Horse Heaven Hills on the south (fig. 2).

The basin-fill deposits (fig. 3) consist predominantly of alluvial fan, loess, dune sand, alluvial terrace, continental sedimentary, and Touchet Formation and Ellensburg Formation deposits. These sediments reach a maximum documented thickness of more than 1,200 ft west of the town of Toppenish and gradually decrease in thickness to $0 \mathrm{ft}$ at the northern end of the basin where the underlying basalt outcrops, but remain about 1,000 ft deep south of the Yakima River until the basin abruptly ends against the steeply emergent Toppenish Ridge (Jones and others, 2006).

About 34 percent of the basin's population is not served by public supply systems and must rely on private wells (Washington State Department of Ecology, 2010). Residential drinking-water wells in the area typically are shallow, with some logged wells as shallow as $10 \mathrm{ft}$ deep. Wells drilled for commercial operations, which typically require a higher flow rate, are more likely to be drilled through the entire thickness of basin sediments to penetrate the Wanapum or Saddle Mountain basalts that underlie the basin. 


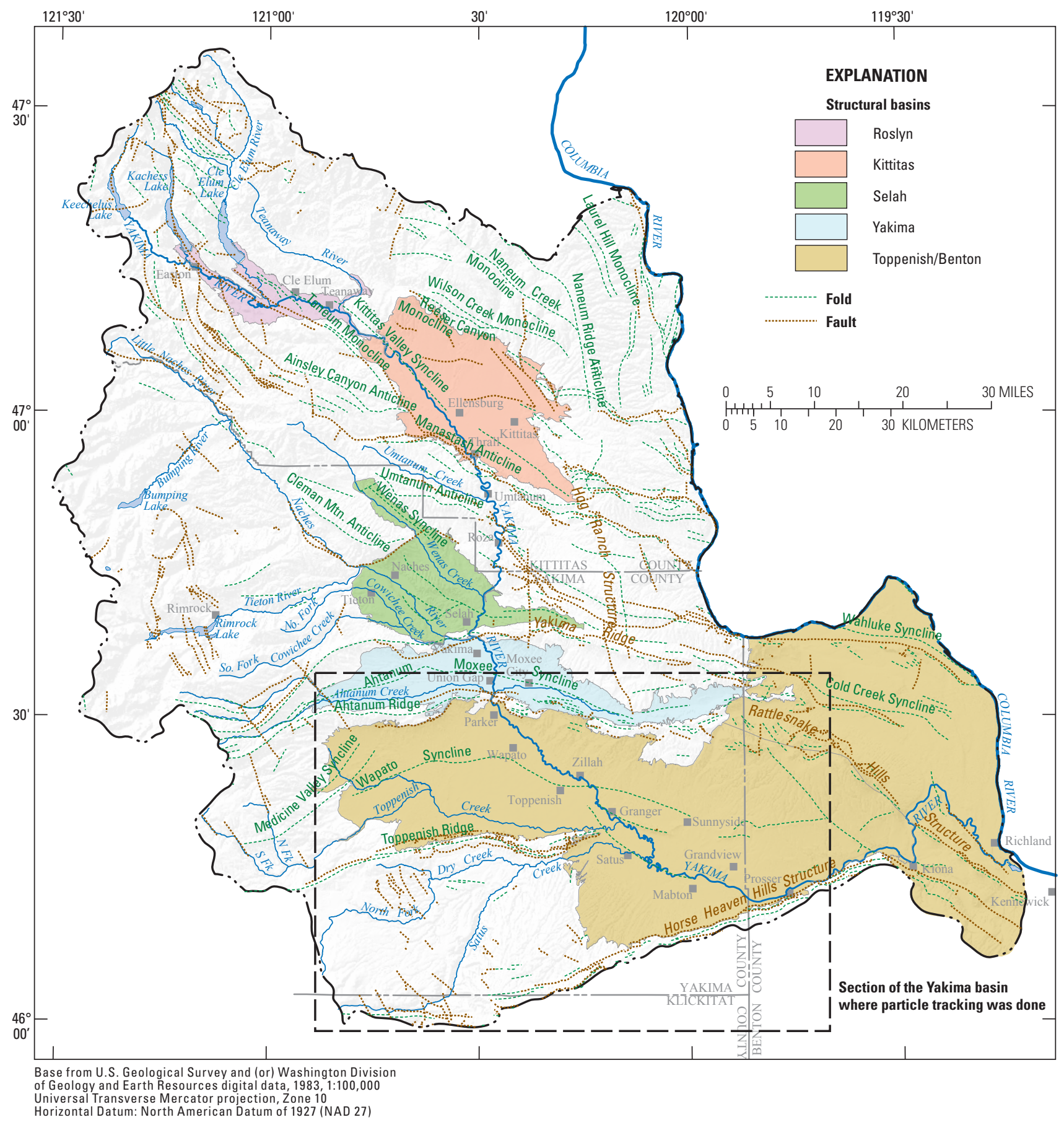

Figure 2. Location of structural basins and geologic structures, Yakima River Basin, Washington. (From Ely and others, 2011.) 


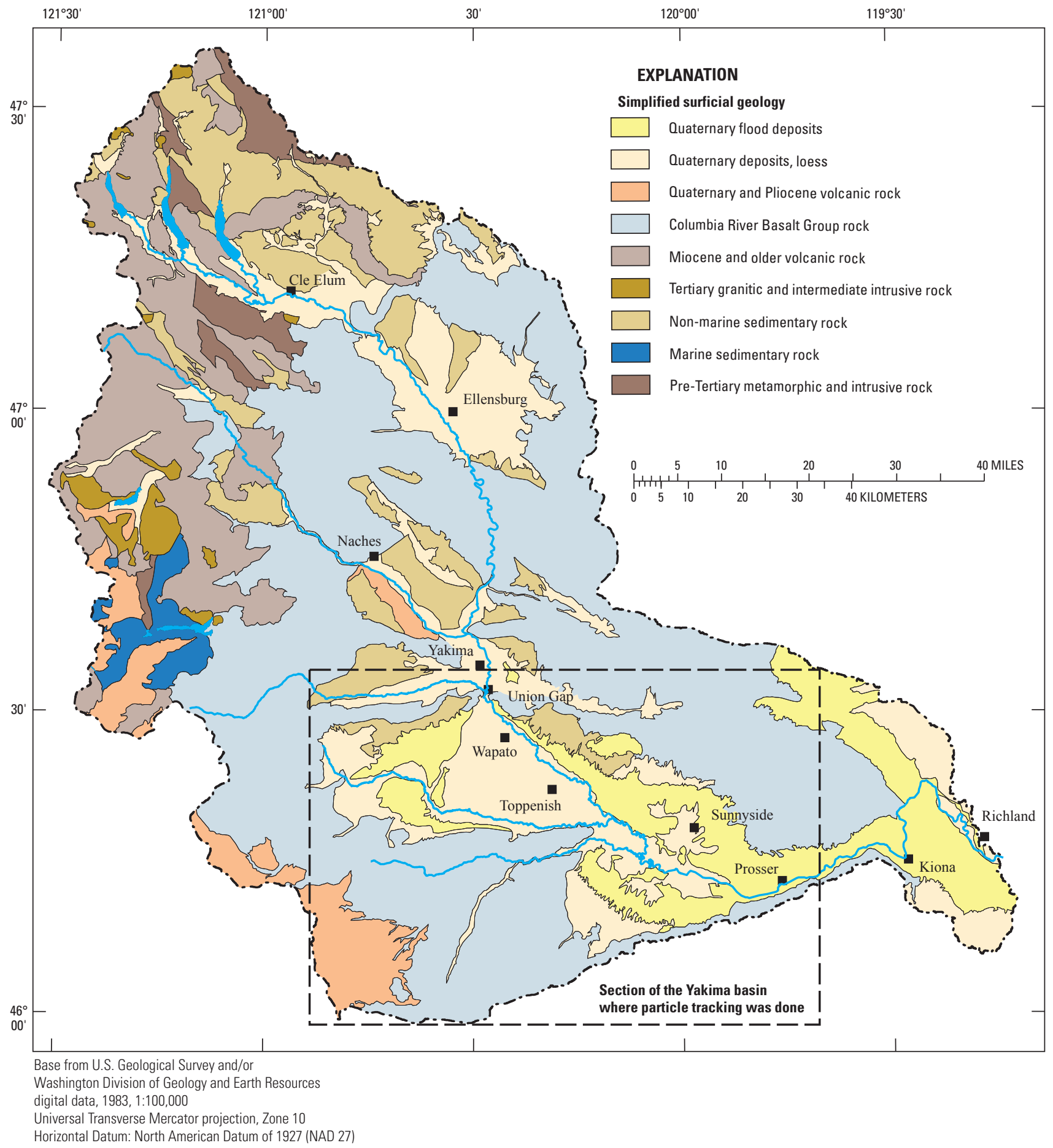

Figure 3. Simplified surficial geology in the Yakima River Basin, Washington. (From Fuhrer and others, 1994.) 
Particle Tracking for Selected Groundwater Wells in the Lower Yakima River Basin, Washington

Irrigated agriculture has been the primary economic activity in the basin since the first non-Indian settlers arrived in 1848. Significant development of irrigation infrastructure began in 1880 and, by 1902, about 120,000 acres were being irrigated, already significantly altering the local groundwaterflow system. As of 2010, about 80 percent of the land area in the basin was used for agriculture, including apples, pears, cherries, peaches, vegetables, hay, mint, and hops (Washington State Department of Ecology, 2010). Dairy operations were greatly expanded starting in the 1980s, and are now (2015) mostly concentrated around the cities of Sunnyside, Grandview, Mabton, and Granger. Current exemptions in State water permitting rules place no restrictions on the amount of water that can be withdrawn by a well owner for the purposes of raising livestock (RCW 90.44.050), so areas with high concentrations of Confined Animal Feeding Operations may be contributing returned water as groundwater recharge at rates greatly exceeding natural recharge for their proportional area representation. At present (2015), there are few regulations governing how dairy operators must construct or manage manure lagoons and no oversight of how animal waste is distributed to surrounding fields (173-303 WAC), leading to concerns that dairy operations are contributing nitrates to the groundwater system in areas immediately upgradient of shallow residential drinking-water wells. The recent growth of the local dairy industry adds a new potential source for nitrate in groundwater, in addition to the application of fertilizers during the 135-year local history of irrigated agriculture. Prior to the completion of the Yakima River Basin groundwater-flow model, there was no rigorous quantitative means to analyze hydrologic connections between specific aquifer-recharge areas and groundwater wells.

\section{Simulation of Particle Tracking}

MODPATH (Pollock, 1994, 2012) is a particle-tracking post-processing package that was developed to compute three-dimensional flow paths using output from steady-state or transient groundwater-flow simulations by MODFLOW, the U.S. Geological Survey numerical (finite-difference) groundwater-flow model. In this study, MODPATH version 5.0 was used for the backtracking of particles in time based on a previously calibrated transient MODFLOW-2000 (Harbaugh and others, 2000) groundwater-flow model of the Yakima River Basin (Ely and others, 2011). The regional Yakima River Basin groundwater-flow model was constructed for the purposes of evaluating regional scale water-management scenarios and surface-water exchanges, not analyses of local-scale impacts at individual wells, so careful and defensible interpretation of the particle-tracking results requires a detailed understanding of how this model was constructed.

\section{Stress Periods}

The transient simulation period extends from October 1 , 1959 , to September 30, 2001, for a total of 42 water years (1960-2001) and 504 monthly stress periods, within each of which specified model stress data such as precipitation or pumping are held constant. The number of time steps in a stress period is equal to the number of days in the month. The monthly stress period and daily time step create efficient model run times while still capturing relevant flow-system characteristics such as seasonal variations in recharge that reflect precipitation and irrigation patterns. Recharge derived from precipitation primarily occurs in the winter at high elevations, and recharge derived from irrigation primarily occurs in the summer on the floors of the sedimentary basins.

The particle backtracking analysis specified particle "starting" locations at the end of the simulation period, and calculated particle movement backwards in time through all 504 monthly stress periods until October 1959 or until reaching a model boundary. Over this period of time, changes to land use, climatic variations, and rapid expansion of groundwater use all significantly influenced groundwaterflow directions. The particle pathlines accordingly are representative of the flow histories of water withdrawn from the sampled wells in September 2001. A more accurate representation of flowpaths to locations sampled in 2011 would require extending the flow model simulation period to include an additional decade beyond 2001, but the results of such an extension are unlikely to qualitatively alter the findings because infrequent installation of new groundwater pumping wells during the 2001-2011 decade would limit additional pumpage data to use in the extended model simulation. The primary benefit of such an extension would be to determine the fate of some additional particles that did not reach land surface during the 42-year backward tracking simulation period.

\section{Discretization}

In MODFLOW, the groundwater-flow system is subdivided laterally and vertically into rectilinear blocks referred to as model cells. The hydraulic properties of the material in each cell are assumed to be homogeneous.

The entire Yakima River Basin was simulated using a model grid of 600 columns and 600 rows with $1,000-\mathrm{ft}^{2}$ horizontal cells, but pathlines were not simulated in some of this active domain because it was external to the Toppenish/ Benton subbasin (fig. 4). No cells included in the previously calibrated and published model were deactivated for any simulation, to avoid any possible disruption of local groundwater head gradients. The part of this grid relevant to particle tracking was only about 300 columns and 200 rows.

Vertically, the model domain was subdivided into 24 model layers, scaled vertically so model cells become increasingly thicker with depth (fig. 5). 


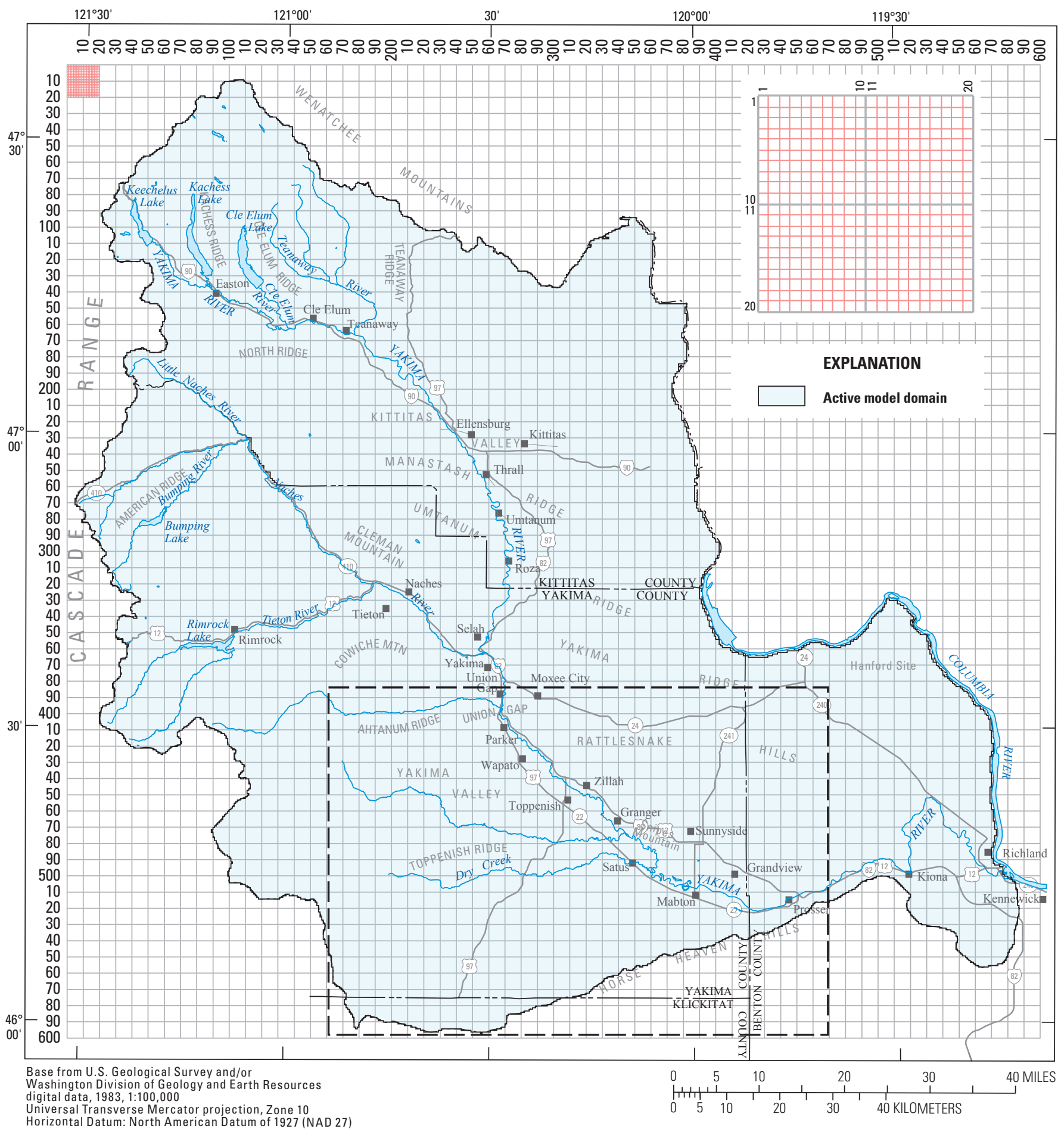

Figure 4. Location and extent of the groundwater-flow model grid used to simulate the Yakima River Basin aquifer system, Washington. The inset depicts the detailed horizontal discretization for the first 20 rows and columns of the model domain. (Modified from Ely and others, 2011.) 


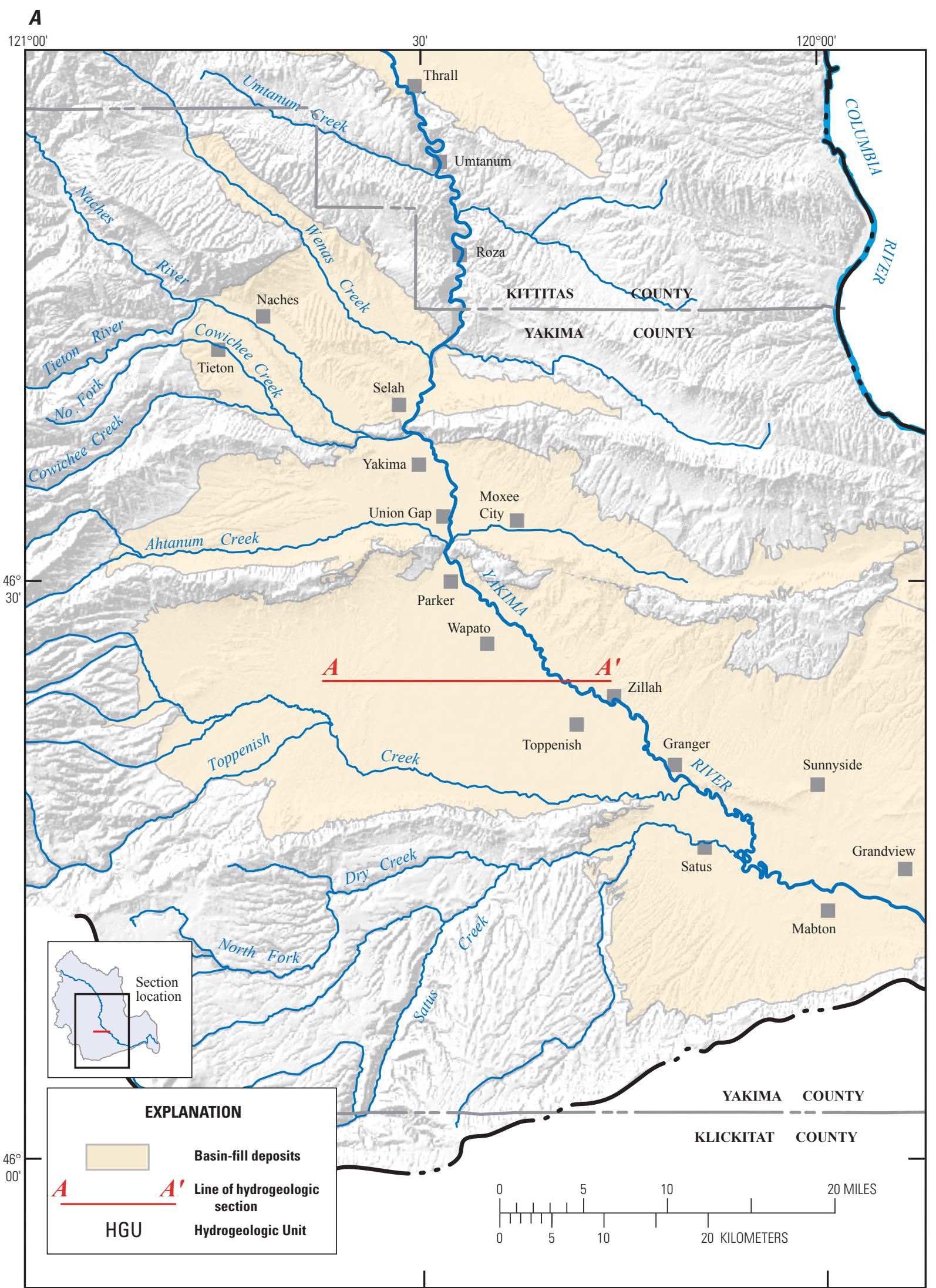

Base from U.S. Geological Survey and/or Washington Division of Geology and Earth Resources digital data, 1983, 1:100,000 Universal Transverse Mercator projection, Zone 10. Horizontal Datum: North American Datum of 1927 (NAD 27)

Figure 5. Location of model cross section through the Toppenish/Benton subbasin $(A)$ and hydrogeologic section showing relation of model hydrogeologic units to model computational layers (B), Yakima River Basin aquifer system, Washington. (Modified from Ely and others, 2011.) 


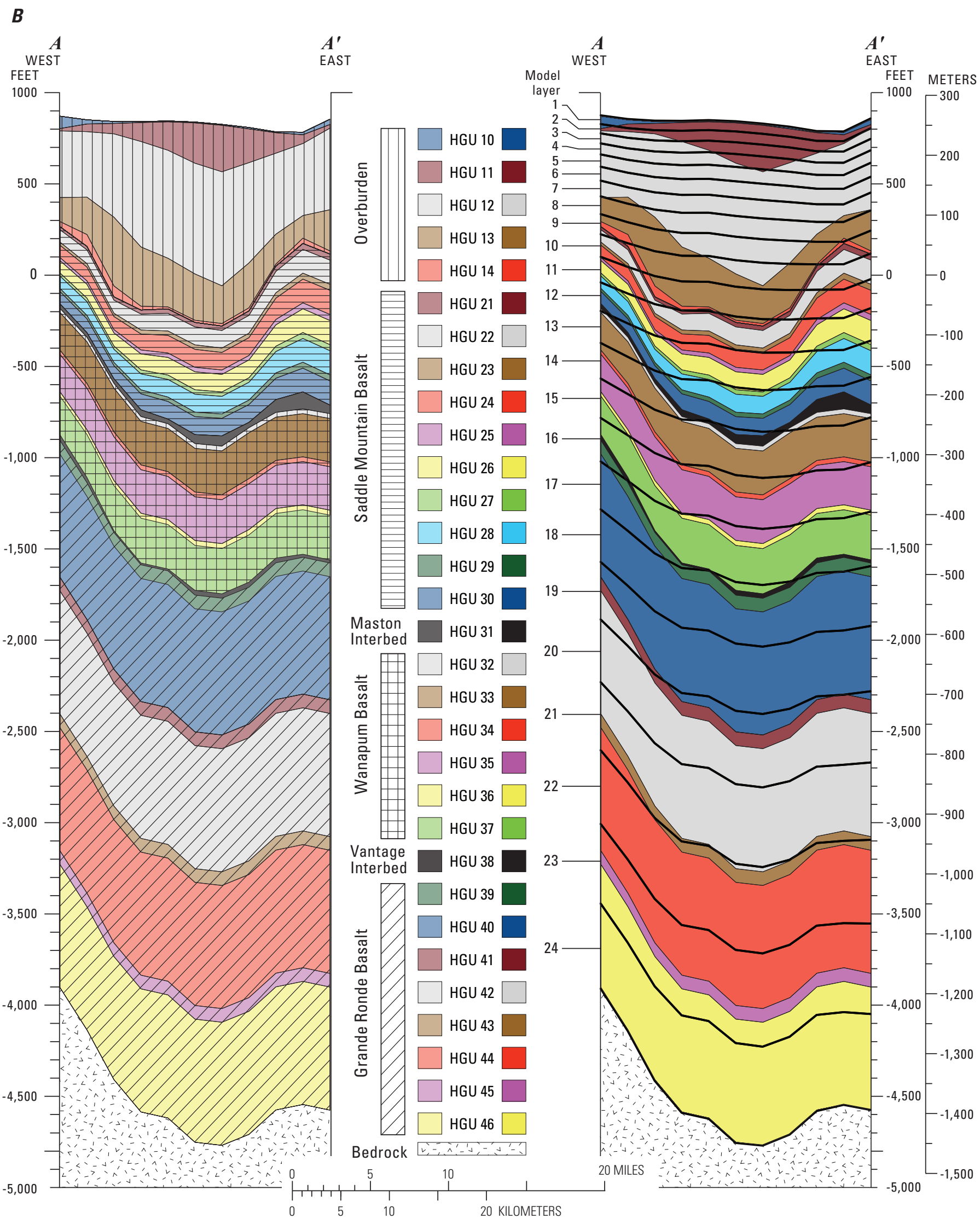

Figure 5.-Continued 
Total model domain thickness ranged from 1,780 to $8,800 \mathrm{ft}$. The percentage of thickness per layer increased parabolically with depth. Each cell in the top layer was specified as 1.00 percent of the total thickness at that model row and column. Each successively lower layer was specified as a slightly larger percentage of total thickness, with the lowest and thickest layer, 24, being 9.82 percent of the total thickness. Mean layer thickness is $43 \mathrm{ft}$ (maximum $88 \mathrm{ft}$ ) for layer 1 and $419 \mathrm{ft}$ (maximum $866 \mathrm{ft}$ ) for layer 24 (table 1). The paraboliclayering approach was used to provide relatively finer vertical discretization for shallow layers of the model (Ely and others, 2011). Hydraulic property values for each hydrogeologic unit in the model were calibrated and then translated into effective properties for each of the 24 computational layers using the Hydrogeologic-Unit Flow package in MODFLOW-2000

(Anderman and Hill, 2000).

Table 1. Descriptive statistics for the thickness of groundwater model layers used to simulate the Yakima River Basin aquifer system, Washington.

[From Ely and others (2011)]

\begin{tabular}{rcccc}
\hline \multirow{2}{*}{$\begin{array}{c}\text { Model } \\
\text { layer }\end{array}$} & $\begin{array}{c}\text { Percentage of } \\
\text { total model } \\
\text { thickness }\end{array}$ & \multicolumn{3}{c}{ Layer thickness, in feet } \\
\cline { 3 - 5 } & 1.00 & 18 & 43 & 88 \\
\hline 1 & 1.06 & 19 & 45 & 93 \\
2 & 1.15 & 20 & 49 & 101 \\
3 & 1.26 & 22 & 54 & 111 \\
4 & 1.41 & 25 & 60 & 124 \\
5 & 1.59 & 28 & 68 & 140 \\
6 & 1.80 & 32 & 77 & 159 \\
7 & 2.03 & 36 & 87 & 179 \\
8 & 2.30 & 41 & 98 & 203 \\
9 & 2.59 & 46 & 110 & 228 \\
10 & 2.92 & 52 & 125 & 257 \\
11 & 3.27 & 58 & 139 & 288 \\
12 & 3.66 & 65 & 156 & 323 \\
13 & 4.07 & 72 & 174 & 359 \\
14 & 4.51 & 80 & 192 & 398 \\
15 & 4.98 & 89 & 212 & 439 \\
16 & 5.48 & 97 & 234 & 483 \\
17 & 6.02 & 107 & 257 & 531 \\
18 & 6.58 & 117 & 281 & 580 \\
19 & 7.17 & 127 & 306 & 632 \\
20 & 7.79 & 139 & 332 & 687 \\
21 & 8.43 & 150 & 359 & 743 \\
22 & 9.11 & 162 & 388 & 803 \\
23 & 9.82 & 175 & 419 & 866 \\
24 & & & & \\
\hline
\end{tabular}

\section{Model Inputs}

Boundary conditions define the locations and manner in which water enters and exits the active model domain. The conceptual model for the aquifer system is that water (1) enters the system as recharge from precipitation (rainfall and snowmelt) and recharge from the delivery and application of surface-water irrigation, and (2) exits the system as streamflow, evapotranspiration, and groundwater pumpage. The specified boundaries of the model coincide as much as possible with natural hydrologic boundaries. Four types of model boundaries were used:

1. No-flow boundaries (groundwater divides),

2. Head-dependent flux boundaries (drains, streams, reservoirs),

3. Specified-head boundaries, and

4. Specified-flux boundaries (recharge, pumpage, and streamflow inflow).

No-flow boundary conditions were specified at the major topographic divides that coincide with the lateral model boundaries other than the Columbia River, which are assumed to be groundwater divides. The topographic divides are either exposed bedrock or basalt. These divides are the crest of the Cascade Range to the west, the drainage-basin divide of the Yakima and Wenatchee Rivers to the north, and Horse Heaven Hills to the south (fig. 6).

Surface-water features including streams and canals were simulated with the MODFLOW Drain (DRN) (Harbaugh and others, 2000) or Streamflow Routing (SFR) packages (Prudic and others, 2004; Niswonger and Prudic, 2005). Drains were used primarily in the headwaters of the Yakima River or for streams that either were ephemeral or had very small annual discharge. This approach added numerical stability to the model in areas far from regions of greatest interest and accounted for the generally gaining upland stream reaches. The simulated quantity of water exiting the system at a drain cell (MODFLOW only allows simulated groundwater flow into a drain cell) is equal to the product of a user-specified drain conductance and the difference between the simulated hydraulic head in the drain cell and the specified elevation of the drain (stream stage). Drain elevation was set at land surface (sampled from the U.S. Geological Survey [USGS] 10-meter Digital Elevation Model) minus $10 \mathrm{ft}$. The drain hydraulic conductance is a function of the surrounding hydrogeologic material and the drain geometry. Information necessary to calculate a drain conductance, such as the distribution and hydraulic conductivity of material near the drain, were unavailable. Drain conductances were divided into groups based on drain size, with values determined by the iterative model calibration process to most accurately reflect measured groundwater heads and streamflows (Ely and others, 2011). 


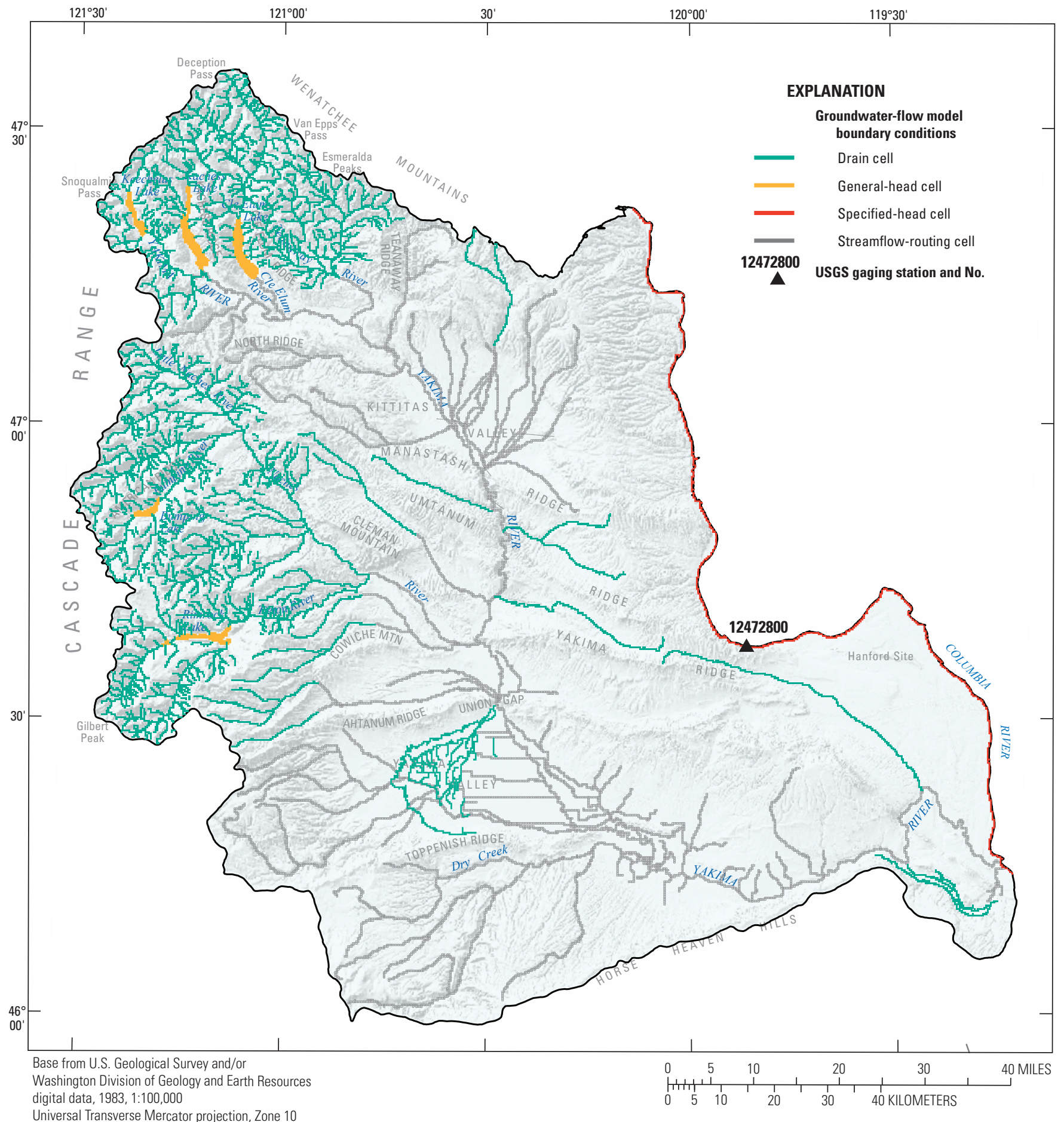

Universal Transverse Mercator projection, Zone 10

Horizontal Datum: North American Datum of 1927 (NAD 27)

Figure 6. Location of the groundwater-flow model boundary conditions for drains, general and specified heads, and streamflow routing cells, Yakima River Basin aquifer system, Washington. (Modified from Ely and others, 2011.) 


\section{Particle Tracking for Selected Groundwater Wells in the Lower Yakima River Basin, Washington}

Excluding drain cells described above, the Yakima River and its tributaries were simulated using the MODFLOW Streamflow-Routing (SFR2) package (Niswonger and Prudic, 2005) to route streamflow and calculate river-aquifer exchanges. The model has 250 SFR2 segments and 8,533 uniquely simulated reaches, and exchange of water between streams and the shallow aquifer system is controlled by the differences between groundwater levels and stream stage for each reach. Some inaccuracy was introduced in the simulation of groundwater flow to and from the streams by using average stream stages and simulating average groundwater elevations within model cells. This uncertainty was not considered a problem in areas of gentle relief, such as the areas containing the groundwater sampling locations used for particle tracking in this analysis, but may contribute to model errors in places where streams are deeply incised. For the Yakima River, stream depth was computed using Manning's equation assuming an eight-point cross section. Average depth and width for the cross sections were based on mean annual streamflow from the USGS National Hydrography Dataset (U.S. Geological Survey, 2014) and regression equations determined by Magirl and Olsen (2009).

Subsurface exchange with the five managed reservoirs in the basin was simulated using the MODFLOW generalhead boundary (GHB) package, using stages derived from USGS 1:24,000-scale topographic maps and held constant throughout the simulation period. This approach neglects the changes in reservoir exchange due to seasonally managed reservoir drawdowns, but the effect is localized to the high-elevation sites near the reservoirs and should have no measureable effect on particle-tracking simulations in the Toppenish/Benton subbasin.

The MODFLOW time variant specified-head (CHD) package was used to simulate the Columbia River on the eastern boundary of the model (fig. 6). Monthly streamflow for the USGS streamgage at Columbia River below Priest Rapids Dam (12472800) during the simulation period ranged from 52,500 to $461,000 \mathrm{ft}^{3} / \mathrm{s}$. Assigned specified head at each cell was based on the stage-discharge relation for the Hanford Reach of the Columbia River at mean annual flow simulated with a two-dimensional hydraulic model (T. Waddle, U.S. Geological Survey, written commun., 2008). Upstream of the several dams along this boundary, head was specified as a constant value equal to the mean pool elevation. Mean differences between monthly pool elevations over the simulation period were less than $5 \mathrm{ft}$, and most differences were less than $3 \mathrm{ft}$.

Groundwater pumping in the Yakima River Basin was estimated as part of this study for eight categories of use during 1960-2001 (Vaccaro and Sumioka, 2006). The eight categories of pumping were:

1. Public water supply (including wells for Group B systems, defined as supplies with less than 15 connections),
2. Self-supplied domestic (permit-exempt wells),

3. Irrigation,

4. Frost protection,

5. Livestock and dairy operations,

6. Industrial and commercial processes,

7. Fish and wildlife propagation, and

8. Groundwater claims.

Methods of data collection, pumpage estimates, reliability of the estimates, and a comparison with appropriated quantities are described by Vaccaro and Sumioka (2006) and Vaccaro and others (2009). By the end of calendar year 1960, total annual pumpage in the basin, excluding standby/reserve pumpage, was about 116,000 acre-ft $\left(160 \mathrm{ft}^{3} / \mathrm{s}\right)$. By 2000, total annual pumpage (excluding standby/reserve rights) was estimated to be about 317,000 acre- $\mathrm{ft}\left(438 \mathrm{ft}^{3} / \mathrm{s}\right)$. Irrigation accounted for about 60 percent of the pumpage, followed by public water supply at about 12 percent. The smallest category of pumpage was for livestock and dairy operations, with pumpage in 2000 estimated to be about 6,700 acre- $\mathrm{ft}$ $\left(9.2 \mathrm{ft}^{3} / \mathrm{s}\right)$. However, total pumpage for this category is not well understood because under Washington law, it is permissible to pump any quantity necessary to meet stockwatering needs ( $\mathrm{RCW}$ 90.44.050), and no information is available on the quantities withdrawn for this purpose. For this reason, local livestock and dairy operations groundwater use may be underestimated by an unknown amount. Pumping locations were simulated in the model using the MODFLOW Well (WEL) package, which assigns volumetric fluxes to a computational model cell and not a specific point within that cell. Most of the wells used to determine starting locations for the particle backtracking analysis were domestic wells not large enough to have been included in the model as unique pumping centers. Such wells were grouped together by quarter section and simulated as a single point withdrawal. As a result of this approach, the particle pathlines presented here are indicative of background groundwater-flow vectors and do not reflect the particle pathline divergence that would be expected for backtracking particles from within a pumping center cone of depression.

Surface recharge to the aquifer system from precipitation and irrigation was simulated with the MODFLOW Recharge $(\mathrm{RCH})$ package. The values used were derived from the Precipitation-Runoff Modeling System (PRMS) (Leavesley and others, 1983) and Deep Percolation Model (Bauer and Vaccaro, 1987; Vaccaro, 2007). The two models were used to simulate two different hydrologic regimes of the Yakima River Basin (Vaccaro and Olsen, 2007), and to estimate groundwater recharge for predevelopment and 2007 land-use and landcover conditions for those regimes (fig. 7). Seasonal variations in recharge due to both precipitation and agricultural applications result in annual changes in groundwater-flow velocities and directions in the shallow sediments of the lower Yakima River Basin. 


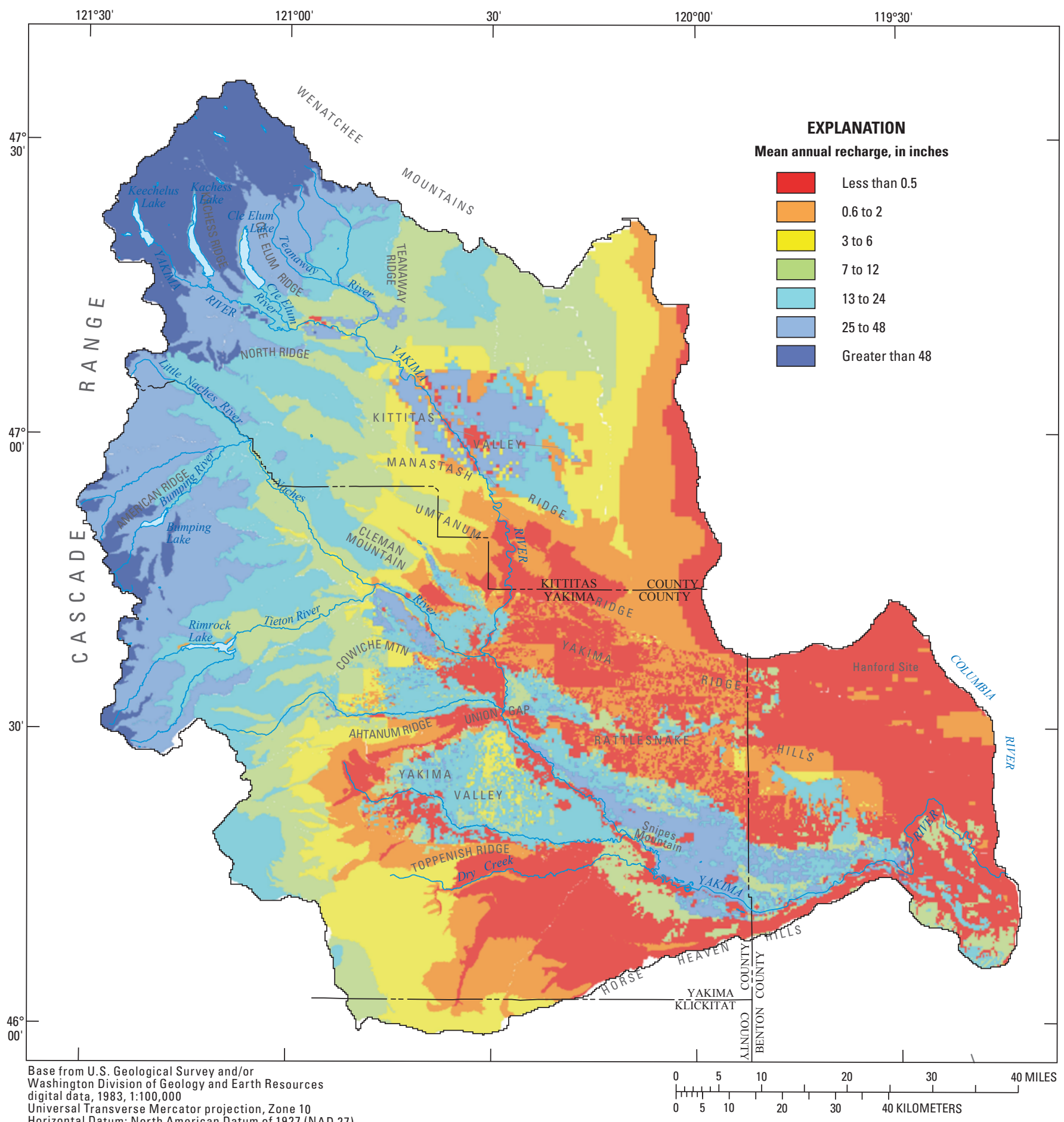

Figure 7. Spatial distribution of mean annual recharge simulated for 1960-2001, Yakima River Basin aquifer system, Washington. Recharge estimates for earlier years reflected historical land-use patterns. (Modified from Ely and others, 2011.) 
Hydrologic properties including hydraulic conductivity and storage coefficients are documented in Ely and others (2011), but one additional model property of specific importance to particle-tracking simulations is the use of hydrologic flow barriers (HFB) implemented with the MODFLOW HFB package (Hsieh and Freckleton, 1993). Previous work indicates that the lateral hydraulic conductivity of members of the Columbia River Basalt Group is reduced by $1-2$ orders of magnitude in areas of intense folding and faulting, especially fault-associated anticlines such as the Yakima Fold and Thrust Belt (Hansen and others, 1994; Packard and others, 1996; Reidel and others, 2002). The HFB package was used to simulate flow barriers for various geologic structures, including Ahtanum and Toppenish Ridges, Rattlesnake Hills, and the Horse Heaven Hills, all of which influence groundwater-flow directions near the Toppenish/Benton subbasin (fig. 8). The degree to which such structures were considered significant to groundwater flow was determined by analysis of measured water-level variations across each structure, in conjunction with the results of model calibrations that included or excluded such effects. Barriers to flow were not simulated as continuous in cases where seasonal changes to groundwater head suggested a hydraulic connection. Where buried beneath basin-fill sediments, the structures were assumed to be absent in the overlying sediments and no barriers were simulated, so such barriers only affected particle pathlines in cases where such pathlines intersected mapped basalt units. In several cases, the simulated particle pathlines make sharp changes in direction around the edges of mapped HFBs, despite poor constraints on the known locations of these features at depth. For this reason, particle pathlines that appear to have sharp corners are likely to be artifacts of a model construct that represents a simplified version of the complex natural system, and may not be indicative of true particle histories.

\section{Calibration}

The model was calibrated with the iterative parameter estimation software package Parallel PEST (Doherty, 2010) using 20,279 water-level measurements from 2,196 wells in the USGS National Water Information System database and 7,056 monthly streamflow measurements from 14 streamgages. Calibrations using groups of hydraulic heads and streamflows were done with observation weights adjusted to ensure equal contribution by these two groups to the model objective function in accordance with the guidelines of Doherty and Hunt (2010). Calibrated model parameters and their values are shown in table 2 , and the comparison between measured and simulated groundwater heads is presented in figure 9. In the Toppenish Basin, head residuals (simulated minus measured head) commonly were less than $10 \mathrm{ft}$ at all locations except those locations near the distal edge of the basin, adjacent to outcropping basalts. Further information about the model calibration procedure, weighting scheme, and sensitivity analysis is included in Ely and others (2011).

\section{Particle Tracking}

A primary objective of this study was to identify the areal extent of the zones of contribution for groundwater wells that EPA identified in April 2011 as having exceeded the nitrate maximum contaminant level of $10 \mathrm{mg} / \mathrm{L}$. EPA collected samples from various groundwater sources in the lower Yakima River Valley and identified excess nitrate in samples from 121 locations (fig. 10).

In most cases, samples were collected from surface access points such as outdoor or kitchen faucets providing groundwater from wells without an identified well log that specified the depth in the aquifer system from which the groundwater was drawn. Because particle-tracking analyses are sensitive to the starting depths of the particles, incorrect identification of the screened intervals of these wells would result in particle pathlines that are consistent with simulated flow directions but may be too long (if the simulated well depth was too deep) or too short (if the simulated well depth was too shallow). In practice, this problem is partially mitigated by the assignment of particle starting locations to a range of depths determined to be appropriate for each well.

To determine these depths, every well log in the Washington State Department of Ecology (2015) well database within a 1-mi radius of each recorded sample location was compiled. For each sample location, well depths were plotted to identify the common depth to which similar wells were screened, on the assumption that boreholes drilled to construct the wells were not drilled any deeper than was necessary to supply sufficient water for the specified use. In cases where a sample location could be identified as being derived from a specific well in the list of well logs, the actual screened depth was used. Assigned well depths for each sample location are provided in appendix A.

With screen depths either from a well log or estimated based on an average of nearest neighbor values, particle starting locations were specified at the edges and center of each 1,000-ft computational model cell that contained an identified sampling location and the known or estimated depth of the well screen. By this process, the 121 identified wells were assigned to 89 unique model cells; some cells contained more than one well. For each of these 89 rectilinear cells, starting particle locations were specified at the middle of each cell, at each of the 8 cell corners, at the midpoint of each of the 12 cell edges, and at the center of each of the 6 cell faces, for a total of 27 particles per cell ( 9 particles in a 3-by-3 array in each of 3 layers). These particle locations encompass the entire volume of the model cells containing the groundwater that was sampled by EPA. The starting particle locations were specified to exist at these cell boundaries at the end of 42-year simulation period, and were tracked backwards in time from these locations. Thus 27 groundwater flowpaths connecting to each of the 89 model cells containing the 121 sample locations were simulated, generating 2,403 unique particle tracks. 


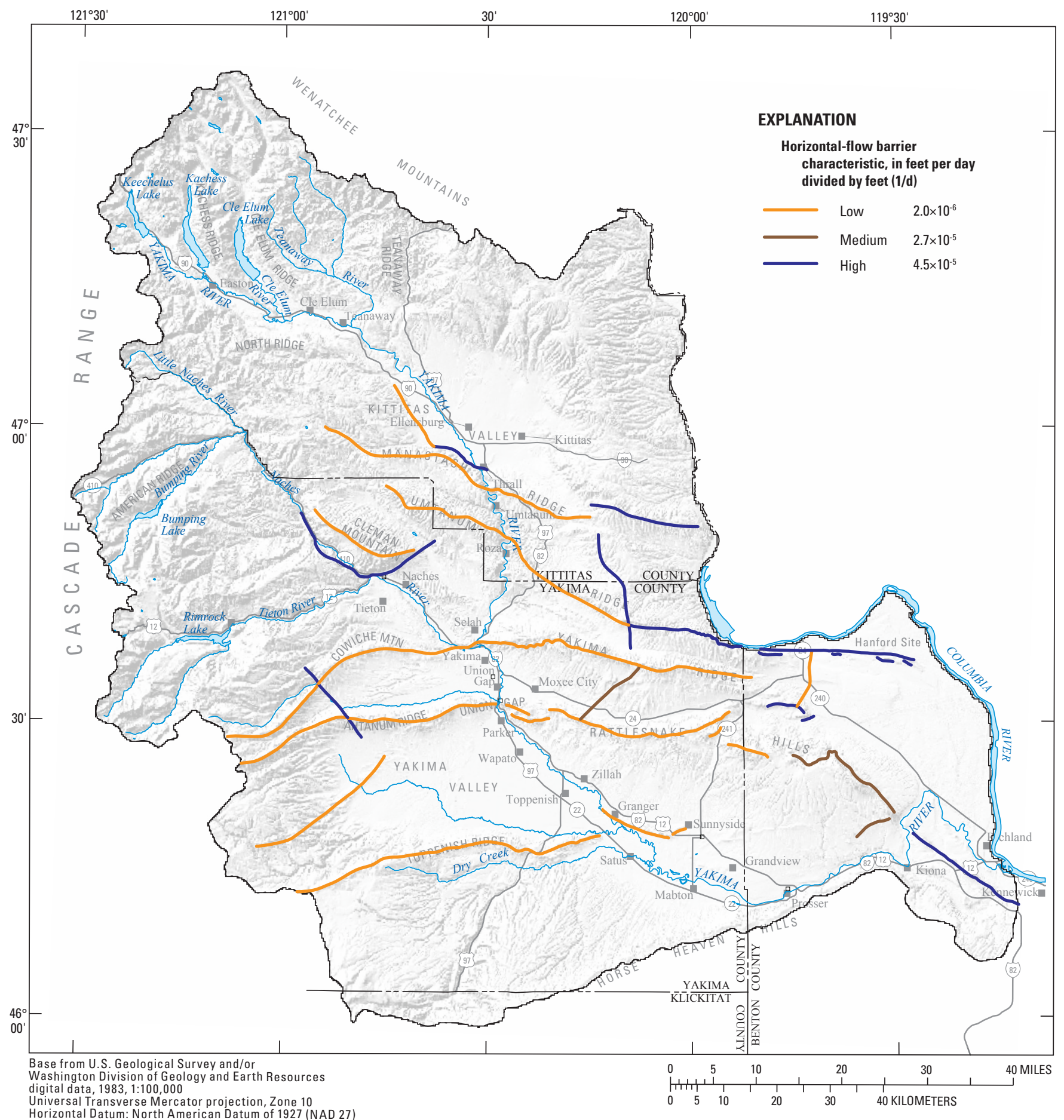

Figure 8. Location of model structures and flow barrier conductivity, Yakima River Basin aquifer system, Washington. (Modified from Ely and others, 2011.) 
Table 2. Calibrated model parameter values for the Yakima River Basin aquifer system, Washington.

[Abbreviations: HGU, hydrogeologic unit; SM, Saddle Mountains unit; WN, Wanapum unit, GR, Grande Ronde; IFZ, interflow zone; INT, flow interior; $\mathrm{ft} / \mathrm{d}$, foot per day; $\mathrm{ft}^{2} / \mathrm{d}$; square foot per day]

\begin{tabular}{|c|c|c|c|c|c|c|c|c|c|}
\hline \multirow{2}{*}{ Hydrogeolgic unit } & \multicolumn{4}{|c|}{ Horizontal hydraulic conductivity (ft/d) } & \multirow{2}{*}{$\begin{array}{c}\text { Vertical } \\
\text { anisotropy }\end{array}$} & \multicolumn{4}{|c|}{ Specific storage $\left(\mathrm{ft}^{-1}\right)$} \\
\hline & Minimum & Mean & Maximum & Constant & & Minimum & Mean & Maximum & Constant \\
\hline HGU 1 & & & & 93.37 & 8.66 & & & & $1.39 \mathrm{E}-02$ \\
\hline HGU 2 & & & & 1.24 & 133.32 & & & & $3.45 \mathrm{E}-04$ \\
\hline HGU 3 & & & & 35.73 & 115.24 & & & & $2.92 \mathrm{E}-04$ \\
\hline HGU 4 & & & & 215.71 & 150.51 & & & & $4.61 \mathrm{E}-02$ \\
\hline HGU 5 & & & & 11.13 & 644.11 & & & & $4.40 \mathrm{E}-05$ \\
\hline HGU 6 & & & & 9.67 & 282.53 & & & & $1.02 \mathrm{E}-04$ \\
\hline HGU 7 & & & & 86.44 & 96.05 & & & & $8.84 \mathrm{E}-04$ \\
\hline HGU 8 & & & & 69.21 & 485.42 & & & & $4.62 \mathrm{E}-05$ \\
\hline HGU 9 & & & & 12.89 & $2,302.48$ & & & & $1.92 \mathrm{E}-05$ \\
\hline HGU 10 & & & & 91.74 & 246.19 & & & & $8.33 \mathrm{E}-05$ \\
\hline HGU 11 & & & & $1,672.30$ & 959.54 & & & & $1.56 \mathrm{E}-03$ \\
\hline HGU 12 & & & & 24.34 & 11.78 & & & & $2.22 \mathrm{E}-04$ \\
\hline HGU 13 & & & & 1.46 & $1,449.37$ & & & & $3.28 \mathrm{E}-04$ \\
\hline HGU 14 & & & & 99.92 & 60.19 & & & & $1.03 \mathrm{E}-04$ \\
\hline HGU 15 & & & & 9.25 & 31.58 & & & & $1.52 \mathrm{E}-04$ \\
\hline HGU 16 & & & & $1,490.37$ & 98.53 & & & & $1.57 \mathrm{E}-03$ \\
\hline HGU 17 & & & & 4.19 & 45.83 & & & & $3.02 \mathrm{E}-04$ \\
\hline HGU 18 & & & & 36.07 & 104.19 & & & & $1.04 \mathrm{E}-04$ \\
\hline HGU 19 & & & & 2.51 & 76.11 & & & & $8.77 \mathrm{E}-05$ \\
\hline HGU 20 & & & & 98.24 & 106.43 & & & & $1.15 \mathrm{E}-04$ \\
\hline SM_IFZ & 35.78 & 119.15 & 261.43 & & $4,336.83$ & $1.51 \mathrm{E}-04$ & 3.39E-04 & $3.73 \mathrm{E}-04$ & \\
\hline SM_INT & 4.91E-04 & $1.66 \mathrm{E}-03$ & $3.56 \mathrm{E}-03$ & & 0.19 & $1.68 \mathrm{E}-05$ & $1.96 \mathrm{E}-05$ & $2.15 \mathrm{E}-05$ & \\
\hline HGŪ31 & 0.36 & 0.88 & 1.57 & & 157.39 & & & & 7.70E-03 \\
\hline WN_IFZ & 25.67 & 129.94 & 278.32 & & 530.33 & $2.83 \mathrm{E}-04$ & $5.99 \mathrm{E}-04$ & $6.76 \mathrm{E}-04$ & \\
\hline WN_INT & $6.92 \mathrm{E}-05$ & $3.51 \mathrm{E}-04$ & 7.49E-04 & & 1.66 & $2.68 \mathrm{E}-05$ & $5.60 \mathrm{E}-05$ & $6.33 \mathrm{E}-05$ & \\
\hline HGŪ38 & & & & 9.31 & 461.85 & & & & $3.22 \mathrm{E}-04$ \\
\hline GR_IFZ & 4.28 & 22.99 & 90.97 & & $2,177.27$ & $1.11 \mathrm{E}-04$ & $2.19 \mathrm{E}-04$ & $2.65 \mathrm{E}-04$ & \\
\hline GR_INT & 7.61E-05 & $3.95 \mathrm{E}-04$ & $1.54 \mathrm{E}-03$ & & 0.32 & $2.43 \mathrm{E}-05$ & 4.64E-05 & $5.76 \mathrm{E}-05$ & \\
\hline HGŪ 47 & & & & 24.88 & 112.90 & & & & $1.35 \mathrm{E}-04$ \\
\hline HGU 48 & 0.01 & 0.03 & 1.09 & & 1.21 & & & & $1.03 \mathrm{E}-04$ \\
\hline
\end{tabular}

Streamflowrouting cells

Yakima River

Tributaries

Drain cells

Headwater streams

Hydraulic-

flow barrier

Low

Medium

High
Conductivity (ft/d)

0.45

0.75

Conductance $\left(\mathrm{ft}^{2} / \mathrm{d}\right)$

$$
323,166.00
$$

Hydraulic characteristic (1/d)

$$
\text { 5.18E-06 }
$$

$3.59 \mathrm{E}-05$

$4.20 \mathrm{E}-04$ 


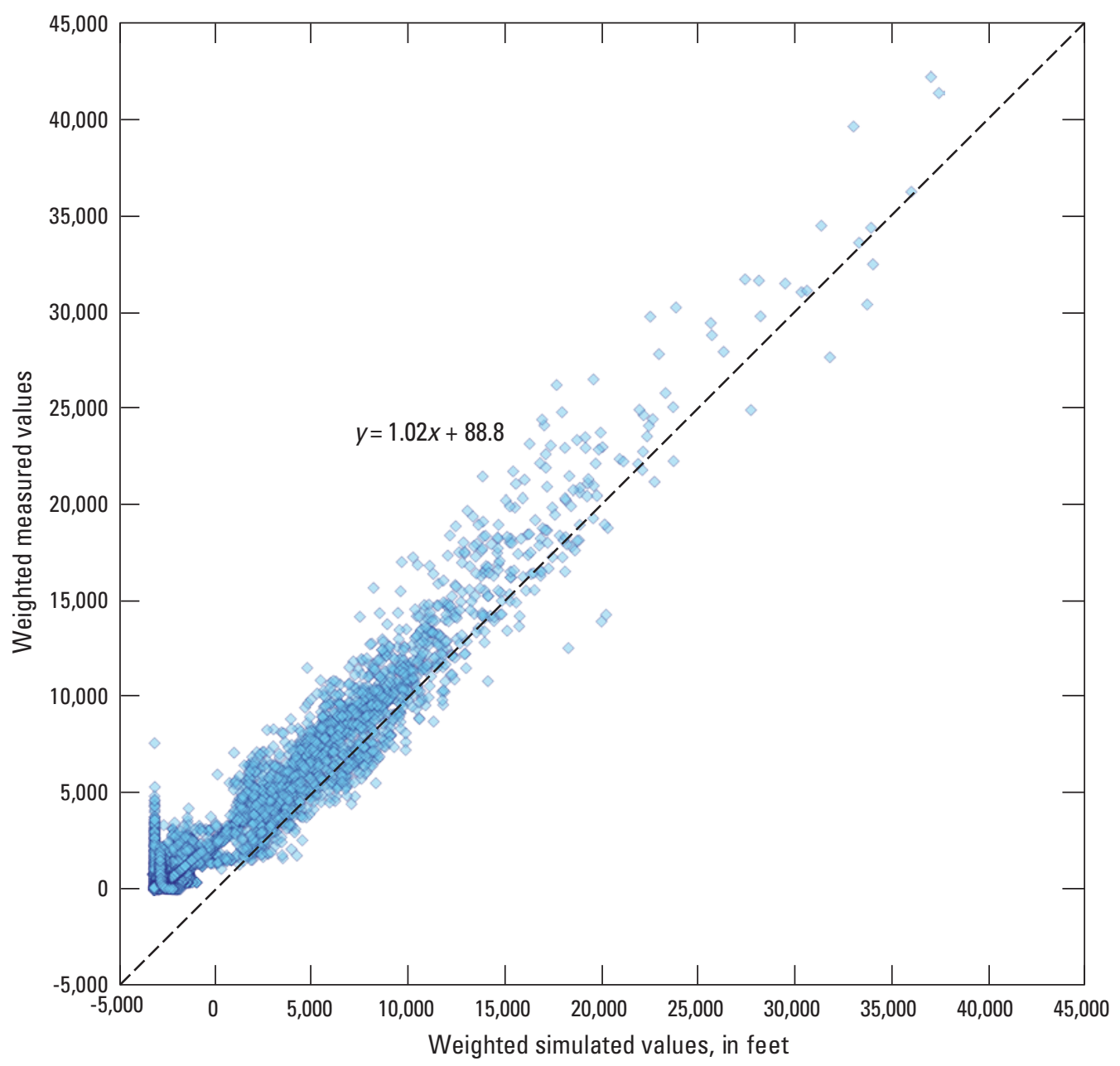

Figure 9. Weighted measured values as a function of weighted simulated values, Yakima River Basin aquifer system, Washington. (From Ely and others, 2011.)

In the absence of any reliable information about the porosity of the sedimentary deposits simulated, MODPATH's default porosity value of 0.01 was used. The uncertainty associated with this value is large, and the time of travel computed from the simulated pathlines may differ from actual time of travel for the same particle starting locations.

MODPATH implements both strong and weak sinks as potential exit points for simulated particles. In the case of weak sinks, some particles can be allowed to pass through a model cell containing a pumping well that does not capture all water in that model cell, but in the particle backtracking analysis all particles were started in model cells containing the pumping well and then backtracked from there. The MODPATH input files were constructed to specify that particles were allowed to pass through weak sinks.
Over the duration of the simulation, most particles eventually intersected the water table and were thus considered to have entered the model as recharge at the water table in less than the 42-year simulation period (fig. 11). Using the aquifer properties described above, the average time-oftravel for all particles was about 10 years and 3 months. This result does not suggest that the contaminated wells of interest are currently pumping water with this age, because some of the particles had not yet reached the water table or other model boundary within the 42 -year simulation duration. Although travel times for some individual particles from shallow starting locations were as short as 22 days, the 1,950-day average time-of-travel for particles that did reach the water table suggests that at least 5 years should be expected to elapse before any modifications to current land-use practices that might change nitrate loading rates would manifest as changes in measured nitrate concentrations at the average well location. 


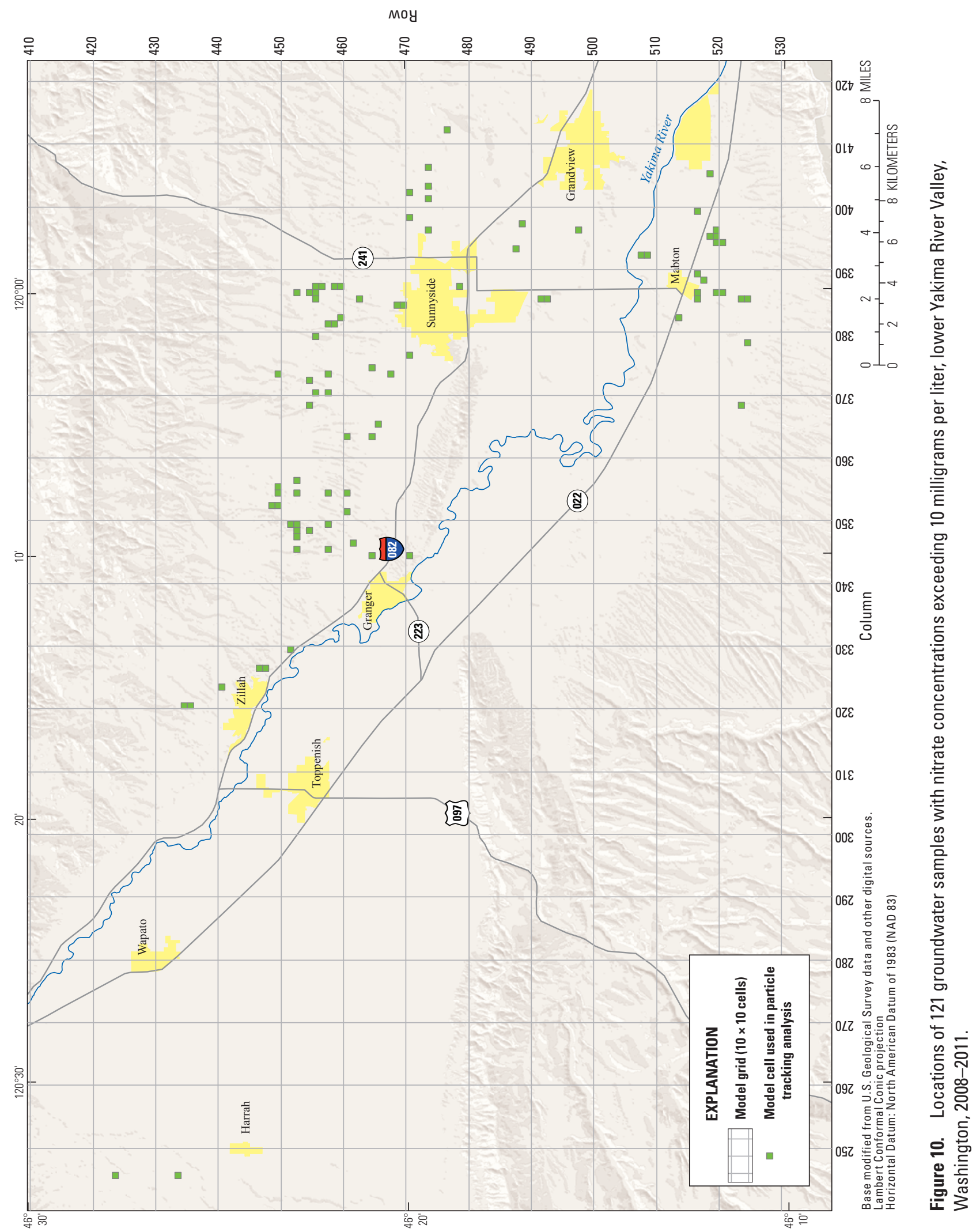




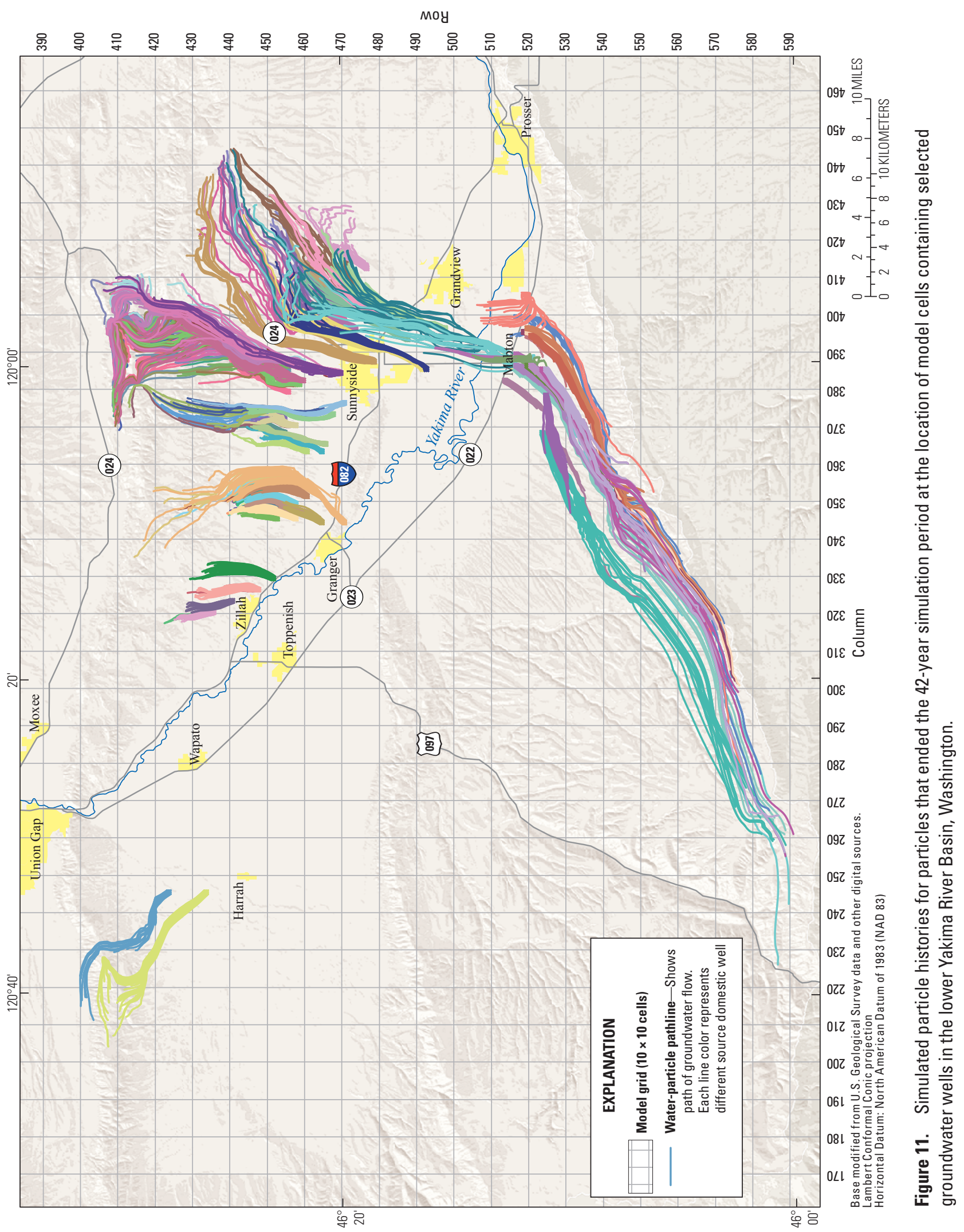


By contrast, the 323 particles that did not reach a model boundary in the 42-year simulation period are associated with groundwater sampling locations for which changes to nitrate loading in the contributing recharge area are decades away from having a measurable effect at the point of withdrawal, and at which future nitrate concentrations may continue to increase as a result of the increasing trend of nutrient application rates over the last 42 years.

Long delays between changes in nitrate loading rates and measurable changes in nitrate concentrations at distant groundwater sampling locations do not imply an aquifer has not yet been affected, only that the changes have not yet propagated to the sampling location. Particle tracking results are summarized in appendix A.

In some locations, structural features such as anticlinal ridges present barriers to groundwater flow, causing sharp changes in hydraulic gradients and groundwater flow directions (fig. 12A). For areas with low hydraulic gradients and high recharge rates derived from seasonal irrigation, fluctuating groundwater levels may cause flow directions and particle pathlines to nearly reverse direction on an annual timescale (fig. 12B).

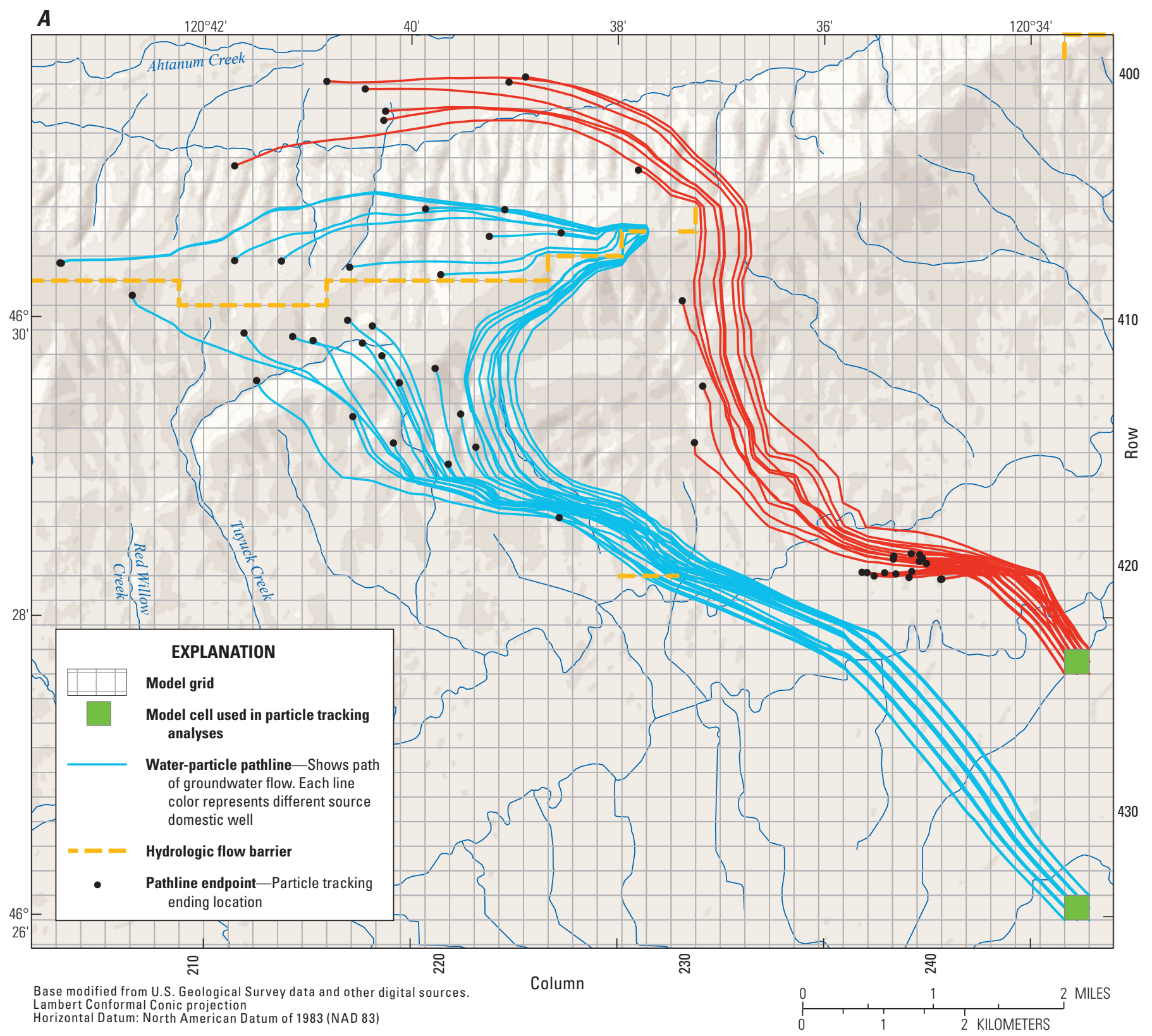

Figure 12. Modeled structural barriers to groundwater flow in some locations cause particle flow paths to change direction sharply $(A)$ and seasonally varying recharge patterns and associated changes in hydraulic head gradients cause some particle paths to temporarily reverse direction $(B)$, Yakima River Basin, Washington. 


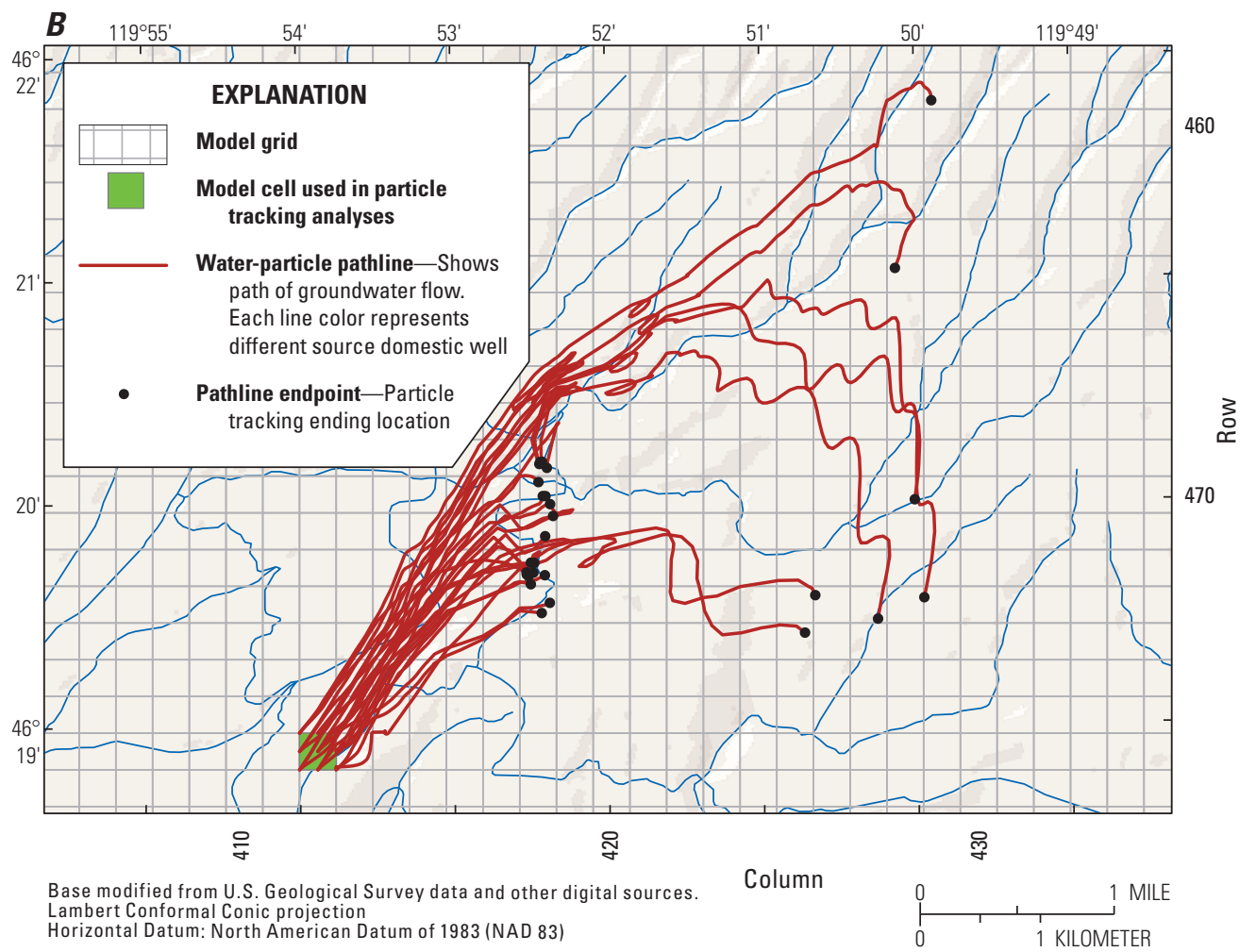

Figure 12.-Continued

In all cases, particle backtracking results record the time for groundwater to travel through the saturated zone to the model cell containing a groundwater well, and neglect additional time that may be required for water to percolate through the unsaturated zone between land surface and the water table. Within the area of interest in the Yakima Basin, unsaturated zone transport is reasonably assumed to be vertical and relatively brief in irrigated areas with shallow water tables.

\section{Delineation of Contributing Areas}

Particle pathlines from each of the 89 individual computational cells containing at least one nitrate-affected well were traced backward by following transient groundwater-flow directions until they reached the water table or other model boundary or the model simulation period ended (fig. 13). For cells with particles that terminated at the water table, the simulated particle ending locations outline the approximate area of land surface that contributed water to that cell at the end of the simulation period (fig. 13A). This area typically is small for cases where the cells contained wells in which simulated pumping rates were too small to cause significant simulated drawdowns throughout the entire model cell. The absence of a cone of depression around the particle starting locations prevents divergence of the particle pathlines. For this reason, the reported areas contributing recharge should be interpreted as the calculated centroid of the true capture area, which may be larger than reported here.

Sources of nitrate loading to the aquifer that are not applied at land surface might contribute to the contaminated wells if they are located anywhere along the particle pathlines (fig. 13B). Examples of potential non-surface nutrient loads include septic systems or improperly sealed or abandoned wellheads that allow surface contamination to rapidly migrate to relevant aquifer depths. Such sources, if present, would expand the area contributing recharge to any specified model cell containing a well to include the entire area between the well location and the most distant particle endpoints, referred to as the areal extent of the zone of contribution (Alley, 2003).

Some parts of the study area include a high density of sampled wells. In those areas, such as northeast of Granger, overlapping particle pathlines are difficult to interpret and have been separated into pathlines representing multiple groups of wells for the purpose of easing visual interpretation (figs. 14A and 14B).

Pathlines originating from model cells near the town of Mabton (fig. 11) show significant divergence depending on depth. Groundwater flow directions in the shallow basin-fill sediments are from the basin margins toward the Yakima River, but flow directions in the deeper basalt units are controlled by groundwater head gradients at depth rather than local surface topography, resulting in flowpaths that appear to cross under the Yakima River as they flow north to contributing recharge areas east of Sunnyside. 


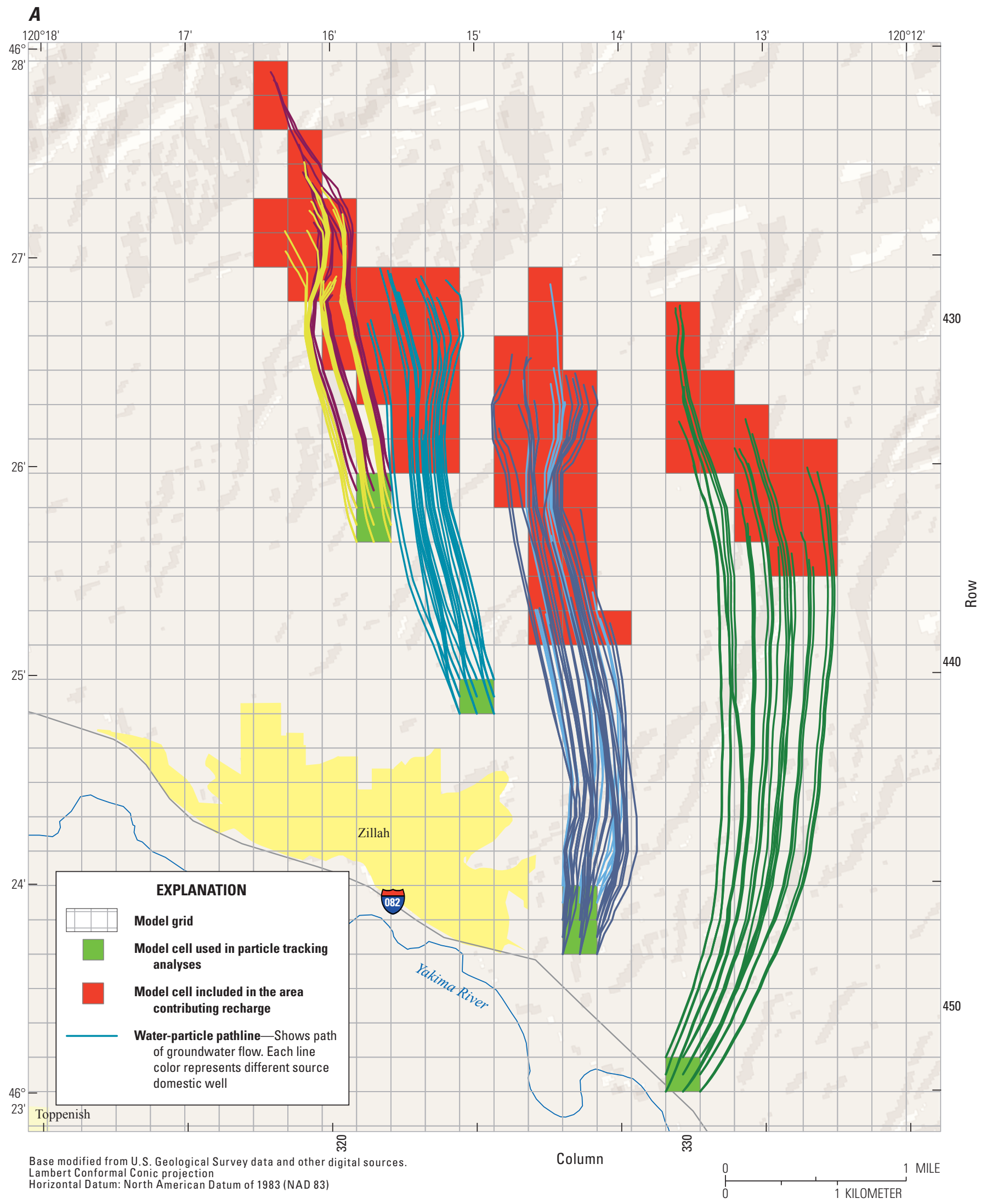

Figure 13. Recharge capture areas defined by $(A)$ particle ending locations outlining the area contributing recharge, and $(B)$ all area circumscribed by particle pathways outlining the areal extent of the zone of contribution for a group of six groundwater sampling locations near Zillah, Washington. 


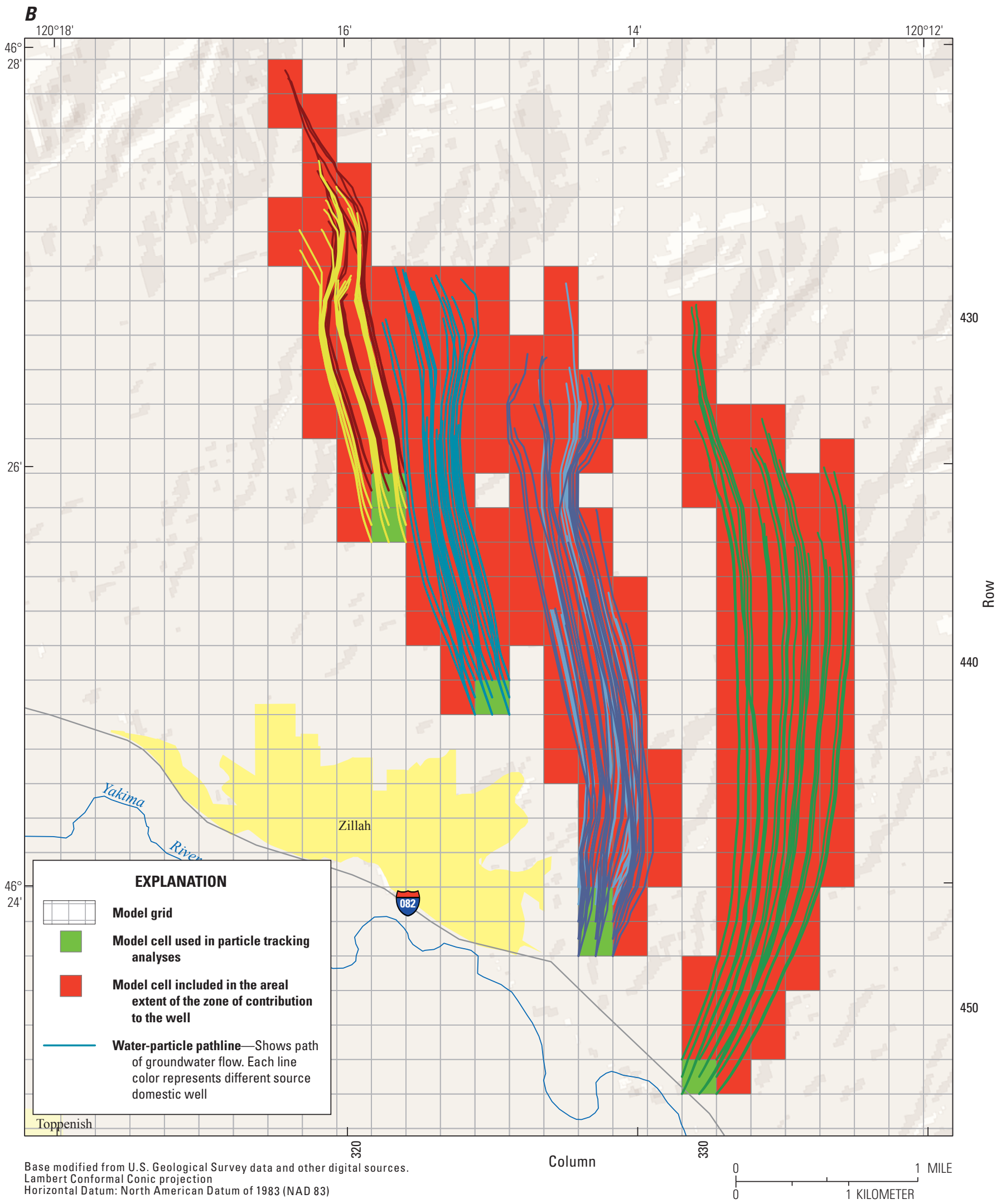

Figure 13.-Continued 


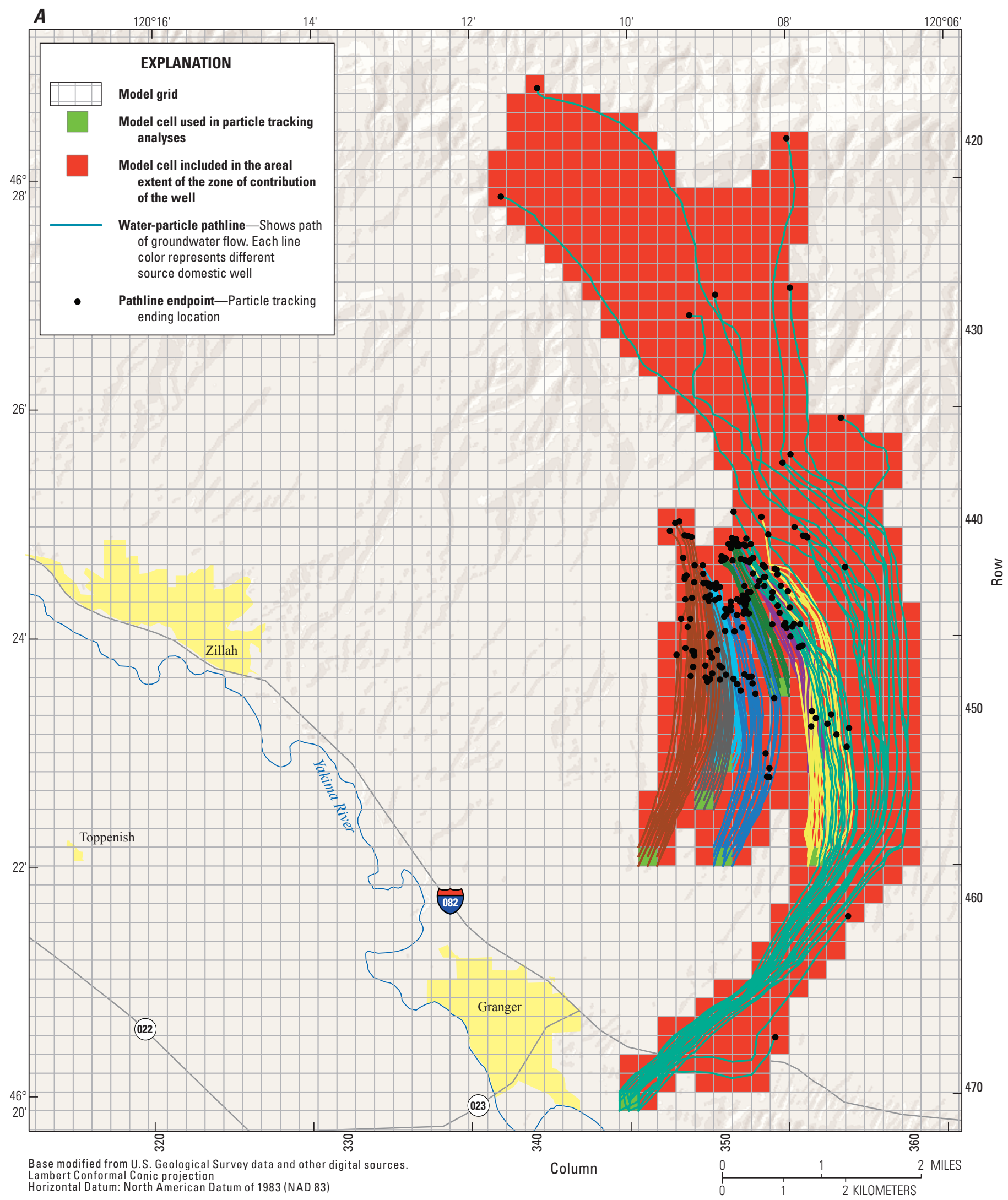

Figure 14. Zones of contribution for a dense area of wells near Granger, Washington, divided into two groups $(A$ and $B)$ to make individual particle pathlines more visible in a location where areas contributing recharge to specific wells overlap heavily. 


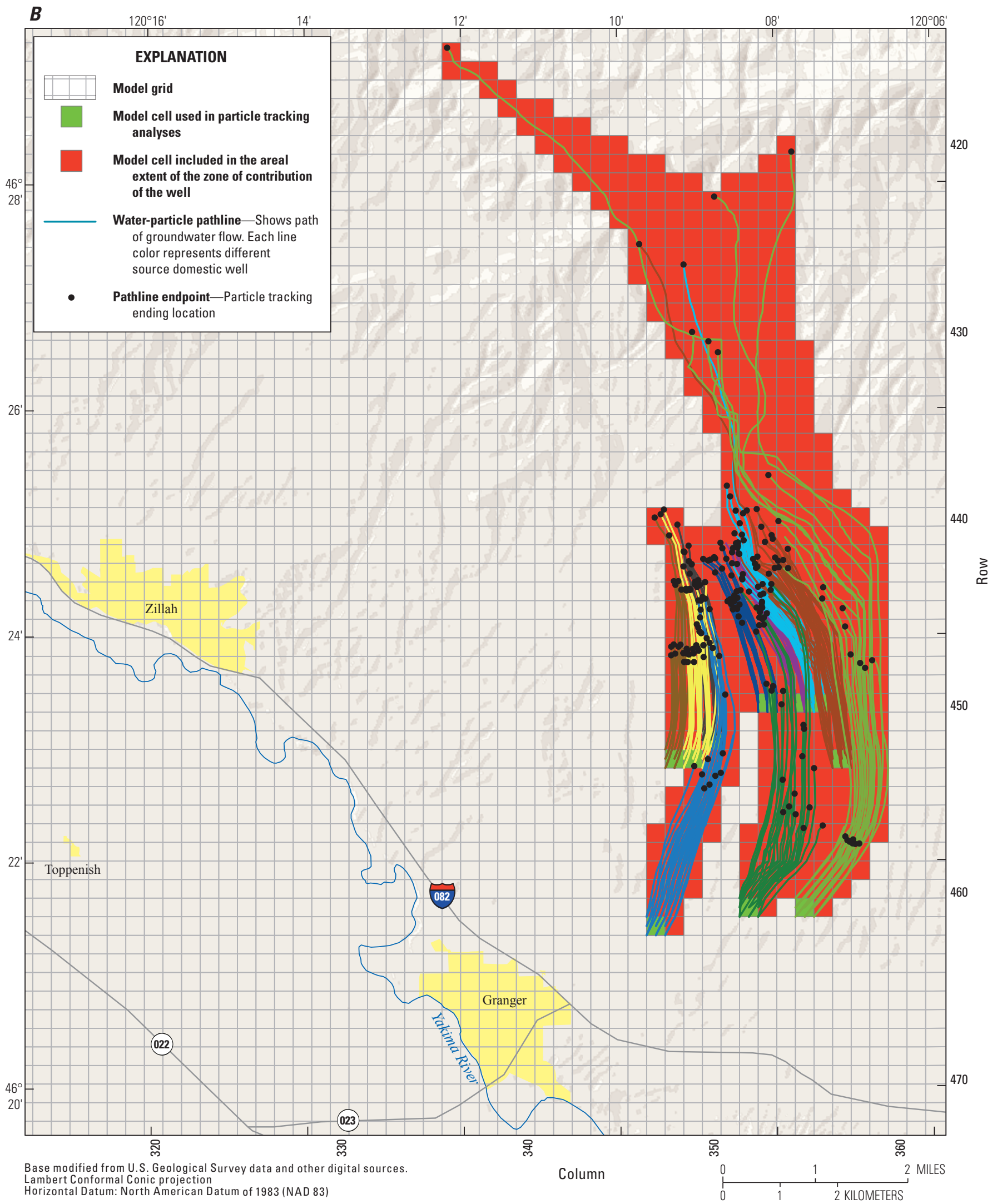

Figure 14.-Continued 
Solute transport in groundwater systems is governed by advection (simulated by MODPATH) and hydrodynamic dispersion (mechanical dispersion and diffusion; not simulated by MODPATH). When a contaminant reaches the water table, the contaminant is advected in the direction of and at the rate of groundwater flow, but the contaminant also mechanically disperses and diffuses longitudinally and transversely to the predominant flow direction. Longitudinal hydrodynamic dispersion tends to smear the contaminant distribution along the longitudinal axis of the flow path and tends to increase the apparent advective flow velocity based on an earlier first arrival time of the contaminant at a given distance. Transverse hydrodynamic dispersion spreads the contaminant plume in the horizontal and vertical directions, roughly perpendicular to the flow direction. Taken together, hydrodynamic dispersion tends to reduce (attenuate) the maximum concentration of contaminant at any one point, but increase the volume of contaminated aquifer material as compared to advective transport. In the context of the particle pathlines presented here, the notable implication of simulations that do not consider hydrodynamic dispersion is that contaminant sources outside of the simulated zones of contribution also may contribute to contaminant concentrations measured at groundwater sampling locations. The degree to which the extent of any zone of contribution is underestimated varies principally with the length of the particle pathlines and variable groundwater flow velocities imposed by heterogeneities of the aquifer material; shorter particle pathlines and relatively less heterogeneous aquifer material are more likely to accurately reflect true zones of contribution, whereas actual zones of contribution associated with longer pathlines are more likely to be larger than simulated. A more complex analysis, such as simulations using the MODFLOWbased contaminant transport code MT3D (Zheng and others, 2001), would be needed to examine the effects of advective and dispersive transport and thus more accurately identify contaminant capture areas for specific model cells containing groundwater wells.

Figure 15 shows the areal extent of the combined zone of contribution simulated for all 89 model cells containing wells with reported nitrate concentrations exceeding $10 \mathrm{mg} / \mathrm{L}$. The combined zone of contribution should not be considered the only potential sources of nitrate contamination in the basin; it represents only the zone that contributed water to these 89 model cells. Contaminant sources outside these areas may contribute to measured concentrations by dispersive transport. The process for selecting wells for nitrate sampling was non-random, so additional areas of high nitrate loading may exist in areas not included in the zone of contribution determined by the model. A more accurate analysis of contaminant presence and transport throughout the study area would include specific concentration loading maps for all sources and would simulate nitrate concentrations for each model cell.

\section{Model Uncertainties and Limitations}

The groundwater model represents an extremely complex natural system with a set of mathematical equations that describe the relevant physical processes governing groundwater flow. Intrinsic to the model is the error and uncertainty associated with the approximations, assumptions, and simplifications inherent in this approach. In addition to those intrinsic errors, hydrologic modeling errors may be the consequence of a combination of errors in the (1) input data, (2) representation of the physical processes by the algorithms and discretization of the numerical model, and (3) parameter estimation during the calibration procedure (Troutman, 1985).

Input data errors include incorrect or poorly known mapped extents or thicknesses of geologic layers. Most measurements used to generate model inputs were done in populated areas near the Yakima River, but even in areas with dense coverage of well logs, variations in lithology or basic sediment properties are sure to exist between the locations of reported values. The recharge estimates used were derived from physical process models that preserve water balance, but uncertainties about the inputs to those models carry over into uncertainties in this model where groundwater-flow velocities, and thus particle time-of-travel, are directly linked to recharge fluxes.

Numerical algorithm errors in a simulation are in part the result of shortcomings in the way the model represents the governing physical processes, and the result of numerical errors in the solutions of the governing partial differential equations. The model inevitably relies on simplifying assumptions and generalizations of the physical processes that complexly affect the results of the simulation. Numerical errors are minimized in the model through use of careful mass-balance and numerical-solution closure criteria. Model discretization errors related to the averaging of surface elevations over a $1,000-\mathrm{ft}^{2}$ model grid cell affect the distribution of aquifer properties and the effective depth of simulated particle starting locations, which are referenced to estimated land surface elevations. For this reason, interpretations of simulation results should be limited to scales several times greater than the model spatial and temporal resolutions of $1,000 \mathrm{ft}$ and 1 month. The semi-analytic nature of the MODPATH particle-tracking results suggests a level of precision that is does not reflect the spatial and temporal averaging inherent in the model construction.

The model calibration process can result in parameterestimation errors of several different types. Inappropriate weighting of observation networks may result in calibrated values outside the accepted range of natural variability if observation types are given unequal cumulative weights. Close agreement between simulated and measured values does not guarantee that the estimated parameter values represent a unique parameter set, and alternate parameter combinations may generate model calibration results that are equally valid, as assessed by the composite-scaled sensitivities, but that 


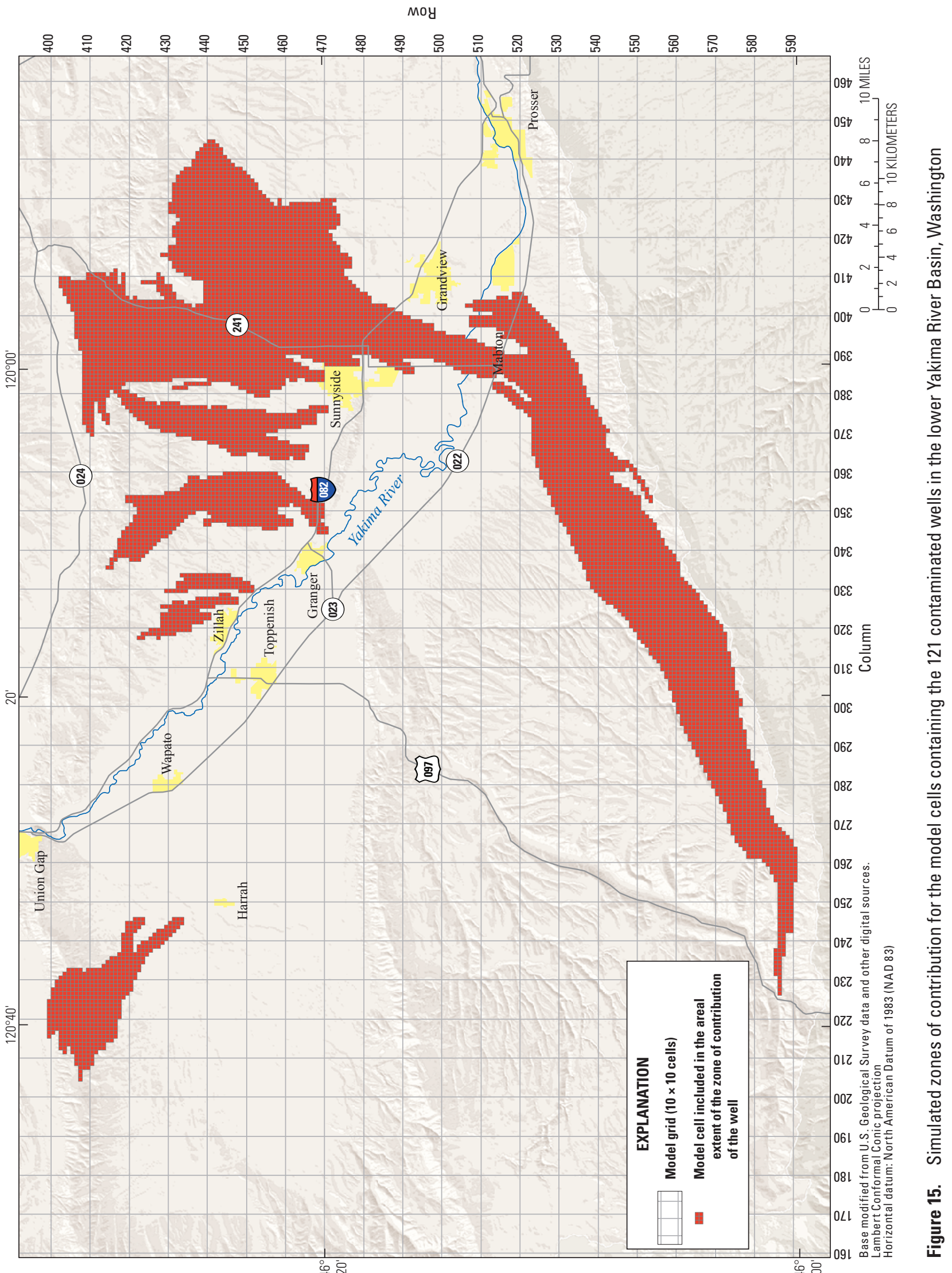


result in locally different values for important parameters such as hydraulic conductivity that would alter particle velocities. Limitations of the observation weighting scheme used to calibrate this model include equal weighting of groundwater head measurements without accounting for relative measurement error, uncertainty in the model layer assignments of some pumping wells, errors in heads used as calibration targets(for example, heads associated with possible perched zones above the saturated, regional groundwater-flow system), and streamflow weights not based on streamflow variance.

These limitations suggest that using this model to simulate the locations of particles derived from specific wells is an analysis best done in aggregate. Location errors on the average of at least one grid cell $(1,000 \mathrm{ft})$ should be expected, with larger errors anticipated for longer flow paths. Average values of particle time-of-travel and direction for each group of 27 particles representing one starting location are representative of all wells contained within that model cell, but distinguishing attribution of surface recharge from specific geographic locations within that area to individual wells contained within that model cell would require a more detailed analysis than is possible at this resolution. Domestic wells were not individually simulated because of the large grid size, and a much finer grid would be needed to more accurately simulate pumping effects at these wells. Including the effects of hydrodynamic dispersion, not simulated by MODPATH, would expand in all directions the effective area from which any given well might capture surface-applied contaminant loads beyond the zones of contribution reported here as sources of water to those wells. Simulation of nitrate transport through the aquifer would require a more detailed approach that accounts for these complexities.

\section{Summary}

Concerns about the health risks associated with high concentrations of nitrate measured in residential drinkingwater wells in the lower Yakima River Basin from 2008 to 2011 have focused renewed attention on land management practices that may be contributing excess nitrate to the shallow groundwater system and drinking-water aquifers. Inorganic fertilizer applied to areas of irrigated agriculture and manure infiltration associated with livestock operations are likely the two largest sources of nitrogen to the system, but their contribution can vary depending on application rate and location. No previous work has attempted to identify the parts of the basin where nutrient application from any source might result in increased nitrate concentrations measured at specific wells because knowledge of the groundwater-flow system required to do this kind of analysis was previously unavailable. Particle tracking analyses can potentially identify where specific nitrate loading rates may result in contamination of drinking-water wells, and at what locations increased nitrate loading rates to groundwater might be possible without affecting drinking-water wells.
Groundwater flow travel-times in the lower Yakima River Basin are shorter in the shallow basin-fill sediments. These sediments consist primarily of alluvial fan, loess, dune sand, alluvial terrace, continental sedimentary, and Touchet Formation and Ellensburg Formation deposits, and typically are several hundred feet thick in the area of interest. The basin sediments are contained by anticlinal ridges of the upper members of the Columbia River Basalt Group, which also may contribute significant groundwater flow to deeper wells. In the absence of strong local pumping centers or high irrigation rates, groundwater flow within the sediments typically is away from the basin margins and towards the Yakima River, and in the direction of downstream river flow. Sudden changes in river stage, such as from reservoir releases in the upper basin, may temporarily disrupt natural groundwater head gradients and alter groundwater-flow directions or velocities.

Groundwater flow in the Yakima River Basin was simulated using the transient three-dimensional finite difference model MODFLOW-2000. Unique flow vectors for every active model cell over a 42-year simulation period were used with the particle tracking post-processing package MODPATH version 5.0 to trace the simulated path of particles that arrived at specified model cells containing groundwater wells. Using MODPATH, these imaginary particles were backtracked from the model cells that contain the wells of interest to the beginning of the model simulation period or to the water table. For each model cell containing one or more wells of interest, the distribution of particle locations at the water table was used to define the area contributing recharge to the cell. Particle starting locations were selected based on the locations and estimated depths of wells with nitrate concentrations exceeding the U.S. Environmental Protection Agency drinking water standard of 10 milligrams per liter.

Particle tracks originating from shallow aquifer locations generally had shorter flowpaths than those from deeper locations. The average time-of-travel for all particles was 3,749 days, but travel times were shorter than the average for 75.4 percent of the particles because a minority of particles originating from deep aquifer locations had very long simulated particle flowpaths. For particles that reached the water table during the 42-year simulation period, the median travel time was 984 days and the median horizontal distance between starting and ending particle locations was 13,194 ft. The model predicts that any changes to nutrient loading rates at these recharge locations should manifest as changes in measured nutrient concentrations in 984 days (median) or 3,749 days (average) at the 89 model cells containing the wells of interest, with significant outliers for pathlines that have much longer and much shorter travel times. Individual particle pathlines ranged in duration from 22 days to the entire 42 -year simulation period.

All particle pathlines and times-of-travel were calculated based on the results of a MODFLOW-2000 model of the Yakima River Basin that makes a series of assumptions about the complex natural groundwater-flow system. The $1,000 \mathrm{ft}$ grid cell size assumes homogeneous properties within 
each model cell, and the seasonal variations in recharge and pumping were reduced to monthly mean values held constant for the duration of each monthly model stress period. Some geologic structures such as anticlines and faults were simulated in the model as flow barriers even though the location and continuity of these structures at depth is unknown. Hydraulic properties used in the model such as hydraulic conductivity were based on previously published ranges for the relevant geologic units, and calibrated using groundwater head and streamflow measurements that did not account for variable observation weighting based on measurement errors. Some model properties, such as porosity, were given default values in the absence of any reliable measurements. The 48 identified geologic units in the model domain were simulated using 24 computational layers and an averaged model cell property weighting scheme that effectively blurs the hydraulic property contrasts that are assumed to exist at well-defined natural geologic contacts. MODPATH uses a semi-analytic particle-tracking algorithm based on advective transport and that neglects effects of hydrodynamic dispersion, suggesting that the simulated zones of contribution are likely to be more accurate for the water contributed to a cell of interest than the contaminants measured in that water. A more complex analysis, such as an analysis using the MODFLOW-based contaminant transport code MT3D, could be combined with specific concentration loading maps of various potential sources to simulate advective and hydrodynamic-dispersive contaminant transport and thus to more accurately identify contaminant capture areas for specific model cells containing groundwater wells as part of a future study addressing these issues. The results presented in this report should be interpreted in the context of the recognized effect of model errors on groundwater flow and the derived particle-tracking results, and the known limitations inherent in the particle-tracking approach.

\section{References Cited}

Alley, W.M., 2003, Terminology used in studies of the source of water to wells under steady-state conditions: U.S. Geological Survey Office of Ground Water Technical Memorandum 2003.02, accessed July 22, 2015, at https:// water.usgs.gov/admin/memo/GW/gw03.02.html.

Anderman, E.R., and Hill, M.C., 2000, MODFLOW-2000, The U.S. Geological Survey Modular Ground-water Model-Documentation of the Hydrogeologic-Unit Flow (HUF) Package: U.S. Geological Survey Open-File Report 00-342, $89 \mathrm{p}$.

Bauer, H.H., and Vaccaro, J.J., 1987, Documentation of a deep percolation model for estimating ground-water recharge: U.S. Geological Survey Open-File Report 86-536, 180 p.
Doherty, J.E., 2010, PEST, Model-independent parameter estimation-User manual (5th ed., with additions): Brisbane, Australia, Watermark Numerical Computing.

Doherty, J.E., and Hunt, R.J., 2010, Approaches to highly parameterized inversion - A guide to using PEST for groundwater-model calibration: U.S. Geological Survey Scientific Investigations Report 2010-5169, 59 p.

Ely, D.M., Bachmann, M.P., and Vaccaro, J.J., 2011, Numerical simulation of groundwater flow for the Yakima River Basin aquifer system, Washington: U.S. Geological Survey Scientific Investigations Report 2011-5155, 90 p.

Hansen, A.J., Vaccaro, J.J., and Bauer, H.H., 1994, Groundwater flow simulation of the Columbia Plateau Regional Aquifer System, Washington, Oregon, and Idaho: U.S. Geological Survey Water-Resources Investigations Report 91-4187, 81 p., 15 pls.

Harbaugh, A.W., Banta, E.R., Hill, M.C., and McDonald, M.G., 2000, MODFLOW-2000, the U.S. Geological Survey modular ground-water model-User guide to modularization concepts and the ground-water flow process: U.S. Geological Survey Open-File Report 2000-92, 121 p.

Hsieh, P.A., and Freckleton, J.R., 1993, Documentation of a computer program to simulate horizontal-flow barriers using the U.S. Geological Survey's modular three-dimensional finite-difference ground-water flow model: U.S. Geological Survey Open-File Report 92-477, 32 p.

Jones, M.A., Vaccaro, J.J., and Watkins, A.M., 2006, Hydrogeologic framework of sedimentary deposits in six structural basins, Yakima River Basin, Washington: U.S. Geological Survey Scientific Investigations Report 20065116, 24 p., 7 pls.

Leavesley, G.H., Lichty, R.W., Troutman, B.M., and Saindon, L.G., 1983, Precipitation-runoff modeling systemUser's manual: U.S. Geological Survey Water-Resources Investigations Report 83-4238, 207 p.

Magirl, C.S., and Olsen, T.D., 2009, Navigability potential of Washington rivers and streams determined with hydraulic geometry and a geographic information system: U.S. Geological Survey Scientific Investigations Report 20095122, 22 p.

Niswonger, R.G., and Prudic, D.E., 2005, Documentation of the Streamflow-Routing (SFR2) Package to include unsaturated flow beneath streams-A modification to SFR1: U.S. Geological Survey Techniques and Methods, book 6, chap. A13, 47 p. 
Packard, F.A, Hansen, A.J., Jr., and Bauer, H.H., 1996, Hydrogeology and simulation of flow and the effects of development alternatives on the basalt aquifers of the Horse Heaven Hills, south-central Washington: U.S. Geological Survey Water-Resources Investigations Report 94-4068, 92 p., 2 pls.

Pollock, D.W., 1994, User's guide for MODPATH/ MODPATH-PLOT, Version 3-A particle tracking postprocessing package for MODFLOW, the U.S. Geological Survey finite-difference ground-water flow model: U.S. Geological Survey Open-File Report 94-464, 236 p.

Pollock, D.W., 2012, User guide for MODPATH, Version 6-A particle-tracking model for MODFLOW: U.S. Geological Survey Techniques and Methods, book 6, chap. A41, 58 p.

Prudic, D.E., Konikow, L.F., and Banta, E.R., 2004, A new streamflow-routing (SFR1) package to simulate streamaquifer interaction with MODFLOW-2000: U.S. Geological Survey Open-File Report 2004-1042, 96 p.

Reidel, S.P., Johnson, V.G., and Spane, F.A., 2002, Natural gas storage in basalt aquifers of the Columbia Basin, Pacific Northwest USA-A guide to site characterization: Richland, Washington, Pacific Northwest National Laboratory [variously paged].

Troutman, B.M., 1985, Errors and parameter estimation in precipitation-runoff modeling - 2, Case Study: Water Resources Research, v. 21, no. 8, p. 1,214-1,222.

U.S. Environmental Protection Agency, 2012, Relation between nitrate in water wells and potential sources in the lower Yakima Valley, Washington: U. S. Environmental Protection Agency, EPA-910-R-12-003.

U.S. Geological Survey, 2014, Hydrography-The National Hydrography Dataset and the Watershed Boundary Dataset: Web site, accessed July 20, 2015, at http://nhd.usgs.gov/ index.html.
Vaccaro, J.J., 2007, A deep percolation model for estimating ground-water recharge - Documentation of modules for the modular modeling system of the U.S. Geological Survey: U.S. Geological Survey Scientific Investigations Report 2006-5318, $30 \mathrm{p}$.

Vaccaro, J.J., Jones, M.A., Ely, D.M., Keys, M.E., Olsen, T.D., Welch, W.B., and Cox, S.E., 2009, Hydrogeologic framework of the Yakima River Basin aquifer system, Washington: U.S. Geological Survey Scientific Investigations Report 2009-5152, 106 p.

Vaccaro, J.J., and Olsen, T.D., 2007, Estimates of groundwater recharge to the Yakima River Basin aquifer system, Washington, for predevelopment and current land-use and land-cover conditions: U.S. Geological Survey Scientific Investigations Report 2007-5007, 30 p.

Vaccaro, J.J., and Sumioka, S.S., 2006, Estimates of groundwater pumpage from the Yakima River Basin aquifer system, Washington, 1960-2000: U.S. Geological Survey Scientific Investigations Report 2006-5205, 56 p.

Van Winkle, Walton, 1914, Quality of the surface waters of Washington: U.S. Geological Survey Water-Supply Paper $339,105 \mathrm{p}$.

Washington State Department of Ecology, 2010, Lower Yakima Valley groundwater quality preliminary assessment and recommendations document: Washington State Department of Ecology Publication No. 10-10-009.

Washington State Department of Ecology, 2015, Well logsWashington State well log viewer: Web site, accessed July 16, 2015, at https://fortress.wa.gov/ecy/waterresources/map/ WCLSWebMap/default.aspx.

Zheng, C., Hill, M.C., and Hsieh, P.A., 2001, MODFLOW-2000, the U.S. Geological Survey modular ground-water model—User guide to the LMT6 package, the linkage with MT3DMS for multi-species mass transport modeling: U.S. Geological Survey Open-File Report 01-82, $43 \mathrm{p}$. 


\section{Appendix A. Summarized Particle-Tracking Information}

Well depths for each sample location where the screened interval depth of the well was not available from a well log were estimated based on the recorded average depth of all similar wells within a 1-mi radius of the sampling location. Model locations and estimated depths (table A1) were used to determine the model layer to which wells and thus particle starting locations were assigned. Particles were distributed throughout each model cell identified by these depths, which results in particles starting from a range of depths equal to the thickness of the assigned layer at that model location prior to initializing the backtracking process.

Nitrate concentrations were greater than $10 \mathrm{mg} / \mathrm{L}$ in 121 domestic wells; these wells were located within 89 unique model cells. Particle pathlines for each of these 89 model cells simulate the historical travel of groundwater in those cells at the end of the simulation period, and are shown in appendix table A1 in approximate order form north to south. The summarized particle-tracking values represent the average value of all particles that were assigned to each of the 89 starting cell locations, but each of those individual particles had a unique pathline and time-of-travel not reported here.

The coordinate starting locations labeled "Starting $\mathrm{X}$ " and "Starting Y" are the locations of the center of the associated model cell, listed in Washington State Plane South, North American Datum of 1983. In this context, starting locations do not represent the actual starting locations on the cell faces but represent the model cells containing wells from which particle backtracking was calculated, and final locations are the places from which those particles originated before flowing towards the wells.
The averaged endpoint distances are the straight line distance between the particle starting and ending locations, and do not represent cumulative pathline length for particles that travel in varying directions or circuitous routes. The average final location model layer of backtracked particles is reported as 1.0 for any cell from which all tracked particles reached land surface within the 42-year simulation period. Values greater than 1.0 for any cell's average final layer of particles indicate that at least some of those particles did not reach land surface. Similarly, an average pathline duration of 15,341 days (42 years) suggests that all particles from that cell were still being actively tracked in the model domain at the end of the 42-year simulation period. In some cases, groundwater sampling locations with associated particle pathlines that ended the backtracking process in a deeper model layer than the one from which they started suggest upward groundwater flow at those locations. Such wells typically are acquiring older groundwater from deeper aquifer layers with longer flow paths, which may have associated recharge capture areas that are relatively far away and thus indicate distant nitrate loads. Particle pathlines that parallel a model no-flow boundary, such as those along the Horse Heaven Hills, may not indicate true groundwater-flow directions, which may include horizontal groundwater flow beneath or through the bounding structure. 
Table A1. Model locations and estimated depth in feet used to determine the model layer to which wells, and thus particle starting locations, were assigned.

[Coordinate start location: "Starting X" and "Starting Y" are the locations of the center of the associated model cell, listed in Washington State Plane South, North American Datum of 1983]

\begin{tabular}{|c|c|c|c|c|c|c|c|c|c|}
\hline \multirow{2}{*}{$\begin{array}{c}\text { Well } \\
\text { Iocation ID }\end{array}$} & \multirow{2}{*}{$\begin{array}{l}\text { Assigned } \\
\text { depth } \\
\text { (feet) }\end{array}$} & \multicolumn{2}{|c|}{ Coordinate start location } & \multicolumn{3}{|c|}{ Model starting location } & \multirow{2}{*}{$\begin{array}{l}\text { Average } \\
\text { final } \\
\text { location } \\
\text { (layer) }\end{array}$} & \multirow{2}{*}{$\begin{array}{c}\text { Average } \\
\text { endpoint } \\
\text { distances } \\
\text { (feet) }\end{array}$} & \multirow{2}{*}{$\begin{array}{c}\text { Average } \\
\text { pathline } \\
\text { duration } \\
\text { (days) }\end{array}$} \\
\hline & & $\begin{array}{l}\text { Starting X } \\
\text { (feet) }\end{array}$ & $\begin{array}{l}\text { Starting Y } \\
\text { (feet) }\end{array}$ & Column & Row & Layer & & & \\
\hline 1 & 100 & 245500 & 176500 & 246 & 424 & 2 & 1.0 & 17,256 & 855.6 \\
\hline 2 & 280 & 245500 & 166500 & 246 & 434 & 5 & 1.0 & 37,638 & $5,276.7$ \\
\hline 3 & 153 & 320500 & 165500 & 321 & 435 & 3 & 1.0 & 7,938 & $1,399.4$ \\
\hline 4 & 152 & 320500 & 164500 & 321 & 436 & 3 & 1.0 & 8,204 & $1,516.4$ \\
\hline 5 & 147 & 323500 & 159500 & 324 & 441 & 3 & 1.0 & 10,071 & 705.9 \\
\hline 6 & 140 & 326500 & 153500 & 327 & 447 & 3 & 1.0 & 11,191 & 564.0 \\
\hline 7 & 143 & 326500 & 152500 & 327 & 448 & 3 & 1.0 & 13,684 & 515.4 \\
\hline 8 & 120 & 352500 & 151500 & 353 & 449 & 3 & 1.0 & 6,197 & $1,137.9$ \\
\hline 9 & 105 & 352500 & 150500 & 353 & 450 & 3 & 1.0 & 6,655 & $1,401.0$ \\
\hline 10 & 120 & 354500 & 150500 & 355 & 450 & 3 & 1.0 & 7,161 & $1,452.2$ \\
\hline 11 & 105 & 355500 & 150500 & 356 & 450 & 3 & 1.0 & 9,209 & $2,254.6$ \\
\hline 12 & 185 & 373500 & 150500 & 374 & 450 & 4 & 2.6 & 18,555 & $10,868.9$ \\
\hline 13 & 123 & 329500 & 148500 & 330 & 452 & 3 & 1.0 & 18,006 & $2,891.8$ \\
\hline 14 & 145 & 349500 & 148500 & 350 & 452 & 3 & 1.0 & 7,536 & 853.9 \\
\hline 15 & 185 & 345500 & 147500 & 346 & 453 & 4 & 1.0 & 6,754 & $1,075.9$ \\
\hline 16 & 154 & 347500 & 147500 & 348 & 453 & 3 & 1.0 & 7,211 & 695.0 \\
\hline 17 & 157 & 348500 & 147500 & 349 & 453 & 3 & 1.0 & 7,308 & 706.8 \\
\hline 18 & 145 & 349500 & 147500 & 350 & 453 & 3 & 1.0 & 7,902 & 743.3 \\
\hline 19 & 115 & 354500 & 147500 & 355 & 453 & 3 & 1.0 & 8,585 & 870.2 \\
\hline 20 & 125 & 356500 & 147500 & 357 & 453 & 3 & 1.0 & 12,171 & $1,486.6$ \\
\hline 21 & 105 & 386500 & 147500 & 387 & 453 & 3 & 1.3 & 41,040 & $6,411.3$ \\
\hline 22 & 140 & 348500 & 145500 & 349 & 455 & 3 & 1.0 & 8,371 & 766.9 \\
\hline 23 & 181 & 368500 & 145500 & 369 & 455 & 4 & 1.0 & 8,737 & $3,025.5$ \\
\hline 24 & 162 & 372500 & 145500 & 373 & 455 & 4 & 1.0 & 8,408 & $1,436.2$ \\
\hline 25 & 210 & 386500 & 145500 & 387 & 455 & 4 & 1.8 & 41,813 & $8,265.5$ \\
\hline 26 & 181 & 370500 & 144500 & 371 & 456 & 4 & 1.0 & 13,496 & $3,100.5$ \\
\hline 27 & 175 & 379500 & 144500 & 380 & 456 & 4 & 1.3 & 44,217 & $9,472.5$ \\
\hline 28 & 135 & 385500 & 144500 & 386 & 456 & 3 & 1.1 & 36,766 & $4,703.0$ \\
\hline 29 & 212 & 386500 & 144500 & 387 & 456 & 4 & 1.1 & 45,411 & $6,086.2$ \\
\hline 30 & 200 & 387500 & 144500 & 388 & 456 & 4 & 2.0 & 43,189 & $8,798.3$ \\
\hline 31 & 315 & 387500 & 143500 & 388 & 457 & 6 & 4.8 & 19,548 & $15,213.7$ \\
\hline 32 & 126 & 345500 & 142500 & 346 & 458 & 3 & 1.0 & 13,885 & $1,147.9$ \\
\hline 33 & 140 & 349500 & 142500 & 350 & 458 & 3 & 1.0 & 10,488 & $1,039.2$ \\
\hline 34 & 145 & 354500 & 142500 & 355 & 458 & 3 & 1.0 & 11,355 & 627.8 \\
\hline 35 & 145 & 370500 & 142500 & 371 & 458 & 3 & 1.0 & 8,401 & 929.6 \\
\hline 36 & 157 & 373500 & 142500 & 374 & 458 & 3 & 2.5 & 25,648 & $8,518.1$ \\
\hline 37 & 182 & 381500 & 142500 & 382 & 458 & 4 & 1.5 & 36,521 & $8,080.9$ \\
\hline 38 & 185 & 381500 & 141500 & 382 & 459 & 4 & 1.1 & 28,949 & $5,858.0$ \\
\hline 39 & 185 & 387500 & 141500 & 388 & 459 & 4 & 2.3 & 44,271 & $7,792.5$ \\
\hline 40 & 175 & 382500 & 140500 & 383 & 460 & 4 & 1.1 & 34,367 & $4,851.5$ \\
\hline 41 & 190 & 387500 & 140500 & 388 & 460 & 4 & 1.0 & 48,707 & $1,689.1$ \\
\hline 42 & 140 & 351500 & 139500 & 352 & 461 & 3 & 1.0 & 10,784 & 620.4 \\
\hline 43 & 137 & 354500 & 139500 & 355 & 461 & 3 & 1.3 & 17,189 & $3,403.4$ \\
\hline 44 & 145 & 363500 & 139500 & 364 & 461 & 3 & 1.0 & 10,160 & 669.4 \\
\hline 45 & 115 & 346500 & 138500 & 347 & 462 & 3 & 1.0 & 11,143 & 569.3 \\
\hline 46 & 185 & 385500 & 137500 & 386 & 463 & 4 & 1.0 & 52,845 & $1,735.8$ \\
\hline 47 & 98 & 344500 & 135500 & 345 & 465 & 2 & 1.0 & 6,036 & 80.9 \\
\hline 48 & 141 & 363500 & 135500 & 364 & 465 & 3 & 1.0 & 15,978 & 907.8 \\
\hline 49 & 140 & 374500 & 135500 & 375 & 465 & 3 & 1.0 & 14,060 & $1,517.2$ \\
\hline
\end{tabular}


Table A1. Model locations and estimated depth in feet used to determine the model layer to which wells, and thus particle starting locations, were assigned.-Continued

[Coordinate start location: "Starting X" and "Starting Y" are the locations of the center of the associated model cell, listed in Washington State Plane South, North American Datum of 1983]

\begin{tabular}{|c|c|c|c|c|c|c|c|c|c|}
\hline \multirow{2}{*}{$\begin{array}{c}\text { Well } \\
\text { location ID }\end{array}$} & \multirow{2}{*}{$\begin{array}{l}\text { Assigned } \\
\text { depth } \\
\text { (feet) }\end{array}$} & \multicolumn{2}{|c|}{ Coordinate start location } & \multicolumn{3}{|c|}{ Model starting location } & \multirow{2}{*}{$\begin{array}{c}\text { Average } \\
\text { final } \\
\text { location } \\
\text { (layer) }\end{array}$} & \multirow{2}{*}{$\begin{array}{c}\text { Average } \\
\text { endpoint } \\
\text { distances } \\
\text { (feet) }\end{array}$} & \multirow{2}{*}{$\begin{array}{c}\text { Average } \\
\text { pathline } \\
\text { duration } \\
\text { (days) }\end{array}$} \\
\hline & & $\begin{array}{l}\text { Starting X } \\
\text { (feet) }\end{array}$ & $\begin{array}{l}\text { Starting Y } \\
\text { (feet) }\end{array}$ & Column & Row & Layer & & & \\
\hline 50 & 141 & 365500 & 134500 & 366 & 466 & 3 & 1.0 & 16,688 & 886.3 \\
\hline 51 & 145 & 373500 & 132500 & 374 & 468 & 3 & 1.0 & 18,141 & 435.3 \\
\hline 52 & 145 & 384500 & 131500 & 385 & 469 & 3 & 1.0 & 22,302 & 422.9 \\
\hline 53 & 160 & 384500 & 130500 & 385 & 470 & 4 & 1.2 & 51,483 & $2,270.0$ \\
\hline 54 & 175 & 384500 & 130500 & 385 & 470 & 3 & 1.0 & 19,644 & 471.7 \\
\hline 55 & 143 & 344500 & 129500 & 345 & 471 & 3 & 1.8 & 33,392 & $7,750.0$ \\
\hline 56 & 145 & 376500 & 129500 & 377 & 471 & 3 & 1.0 & 17,521 & 475.0 \\
\hline 57 & 163 & 398500 & 129500 & 399 & 471 & 4 & 1.2 & 33,009 & $4,496.7$ \\
\hline 58 & 142 & 402500 & 129500 & 403 & 471 & 3 & 1.0 & 20,924 & $2,907.2$ \\
\hline 59 & 132 & 396500 & 126500 & 397 & 474 & 3 & 1.0 & 20,150 & 735.5 \\
\hline 60 & 150 & 401500 & 126500 & 402 & 474 & 3 & 1.0 & 22,679 & $1,700.2$ \\
\hline 61 & 142 & 403500 & 126500 & 404 & 474 & 3 & 1.0 & 21,108 & $1,369.0$ \\
\hline 62 & 115 & 406500 & 126500 & 407 & 474 & 3 & 1.0 & 26,205 & $3,162.1$ \\
\hline 63 & 250 & 412500 & 123500 & 413 & 477 & 5 & 1.0 & 10,883 & $9,019.2$ \\
\hline 64 & 118 & 387500 & 121500 & 388 & 479 & 3 & 1.1 & 46,079 & $2,354.1$ \\
\hline 65 & 100 & 393500 & 112500 & 394 & 488 & 3 & 1.0 & 24,055 & 293.6 \\
\hline 66 & 100 & 397500 & 111500 & 398 & 489 & 3 & 1.0 & 33,941 & 851.1 \\
\hline 67 & 110 & 385500 & 108500 & 386 & 492 & 3 & 1.0 & 37,167 & 849.6 \\
\hline 68 & 110 & 385500 & 107500 & 386 & 493 & 3 & 1.0 & 35,269 & 468.1 \\
\hline 69 & 122 & 396500 & 102500 & 397 & 498 & 3 & 1.0 & 29,424 & $2,358.6$ \\
\hline 70 & 142 & 392500 & 92500 & 393 & 508 & 3 & 2.4 & 47,572 & $7,680.7$ \\
\hline 71 & 142 & 392500 & 91500 & 393 & 509 & 3 & 4.6 & 64,334 & $14,373.4$ \\
\hline 72 & 139 & 382500 & 86500 & 383 & 514 & 3 & 1.0 & 9,787 & 759.3 \\
\hline 73 & 110 & 385500 & 83500 & 386 & 517 & 3 & 2.3 & 37,180 & $5,026.8$ \\
\hline 74 & 130 & 386500 & 83500 & 387 & 517 & 3 & 2.7 & 19,671 & $5,304.6$ \\
\hline 75 & 110 & 389500 & 83500 & 390 & 517 & 3 & 4.3 & 17,225 & $5,594.3$ \\
\hline 76 & 100 & 399500 & 83500 & 400 & 517 & 3 & 5.0 & 52,788 & $14,720.4$ \\
\hline 77 & 110 & 388500 & 82500 & 389 & 518 & 3 & 4.0 & 9,000 & $5,470.4$ \\
\hline 78 & 90 & 395500 & 81500 & 396 & 519 & 2 & 1.0 & 23,625 & $1,874.2$ \\
\hline 79 & 139 & 405500 & 81500 & 406 & 519 & 3 & 8.8 & 18,723 & $15,341.0$ \\
\hline 80 & 130 & 386500 & 80500 & 387 & 520 & 3 & 2.7 & 18,735 & $5,378.4$ \\
\hline 81 & 90 & 394500 & 80500 & 395 & 520 & 2 & 1.0 & 9,050 & 614.6 \\
\hline 82 & 90 & 395500 & 80500 & 396 & 520 & 2 & 1.0 & 21,185 & $1,573.5$ \\
\hline 83 & 90 & 396500 & 80500 & 397 & 520 & 2 & 1.0 & 20,771 & $1,107.2$ \\
\hline 84 & 130 & 386500 & 79500 & 387 & 521 & 3 & 2.7 & 27,998 & $6,039.7$ \\
\hline 85 & 90 & 394500 & 79500 & 395 & 521 & 2 & 1.0 & 13,317 & $1,199.0$ \\
\hline 86 & 125 & 368500 & 76500 & 369 & 524 & 3 & 4.6 & 86,411 & $12,180.2$ \\
\hline 87 & 125 & 385500 & 76500 & 386 & 524 & 3 & 3.0 & 51,891 & $8,616.3$ \\
\hline 88 & 240 & 378500 & 75500 & 379 & 525 & 5 & 9.1 & 20,601 & $15,341.0$ \\
\hline 89 & 125 & 385500 & 75500 & 386 & 525 & 3 & 3.2 & 40,115 & $7,655.5$ \\
\hline
\end{tabular}



Publishing support provided by the U.S. Geological Survey

Science Publishing Network, Tacoma Publishing Service Center

For more information concerning the research in this report, contact the Director, Washington Water Science Center

U.S. Geological Survey

934 Broadway, Suite 300

Tacoma, Washington 98402

http://wa.water.usgs.gov 
